Western University Scholarship@Western

Centre for the Study of International Economic Centre for the Study of International Economic

Relations Working Papers

Relations

1982

\title{
Is Sterling M3 the Right Aggregate?
}

Robin Bade

Michael Parkin

Follow this and additional works at: https://ir.lib.uwo.ca/economicscsier_wp

Part of the Economics Commons

\section{Citation of this paper:}

Bade, Robin, Michael Parkin. "Is Sterling M3 the Right Aggregate?." Centre for the Study of International Economic Relations Working Papers, 8217C. London, ON: Department of Economics, University of Western Ontario (1982). 
CENTRE FOR THE STUDY OF INTERNATIONAL ECONOMIC RELATIONS

WORKING PAPER $8217 \mathrm{C}$

IS STERLING M3 THE RIGHT AGGREGATE?

Robin Bade

and

Michae1 Parkin

This paper contains preliminary findings from research work still in progress and should not be quoted without prior approval of the author.

DEPARTMENT OF ECONOMICS

THE UNIVERSITY OF WESTERN ONTARIO

LONDON, CANADA

N6A $5 \mathrm{C} 2$ 
IS STERLING M3 THE RIGHT AGGREGTE?

\author{
by \\ Robin Bade \\ and \\ Michael Parkin \\ Department of Economics \\ University of Western Ontario \\ London \\ Canada
}

November, 1982

An earlier version of this paper under the title "U.K. Monetary Policy in the $1970 \mathrm{~s}$ " was presented at the conference on "Monetarism in the U.K.," held at the City University, London, 23-24 September 1981. We are grateful (but do not implicate) the participants in that conference and e specially Sean Holly and Andrew Longbottom for providing us with recent (unpublished) papers in this area. We are also grateful to Ronald Wirick and other participants in the Money Workshop of the University of Western Ontario for helpful comments on an earlier draft and to Jeremy Greenwood and Aman Ullah for valuable help on statistical matters.

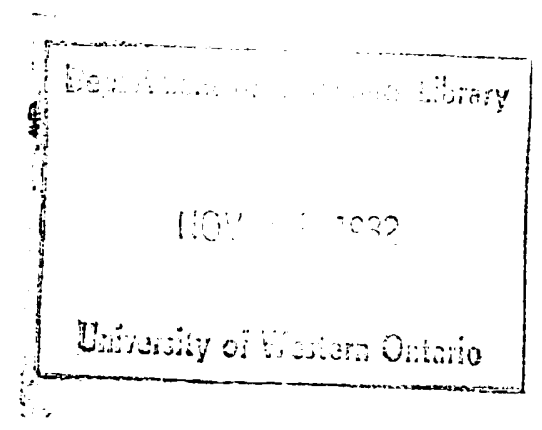




\author{
I. INTRODUCTION \\ II. BANK OF ENGLAND'S RATIONALE FOR TARGETING ON £M3 \\ III. EVIDENCE FROM DEMAND FOR MONEY STUDIES \\ IV. EVIDENCE FROM "REDUCED FORMS" AND CAUSALITY TESTS \\ V. NEW EVIDENCE FROM CAUSALITY TESTS \\ VI. INTERPRETING THE EVIDENCE \\ VII. CONCLUSIONS
}


IS STERLING M3 THE RIGHT AGGREGATE?

\section{IFTRODUCTION}

Since the election of Mrs. Thatcher in 1979 world attention has been focused on United Kingdom economic policy in general and monetary policy in particular. This paper attempts to evaluate the monetary strategy which has evolved through the 1970 s and which is now being pursued with vigor by the Thatcher government. The objective of policy is to slow down inflation with minimum effects on unemployment and deviations of real output from trend. This objective is being pursued by aiming for a target growth rate of a monetary aggregate, sterling $M 3$, which is announced in advance and which follows a declining path for some years into the future.' The specific questions addressed are, first: is there any evidence from United Kingdom experience that any monetary aggregate influences the behavior of prices and in such a way as to make it conceivable that inflation could be brought under control while doing little damage to the rate of unemployment and level of real output? Second, is the particular monetary aggregate chosen by the authorities (sterling M3) the correct one?

In part, the paper attempts to answer these questions by drawing on the work of others. In reviewing the existing literature, however, it became apparent that a satisfactory answer to the above questions could not be arrived at on the basis of work already done. Consequently, the paper also presents some new empirical findings on several crucial issues relating to causal orderings amongst monetary aggregates, inflation and real output. The paper proceeds in the following order. First in Part II, a brief description is presented of the behavior of the growth rate of the 
various monetary aggregates through the 1970 s and the Bank of England's own reasons for choosing sterling $\mathrm{M} 3$ as the intermediate target for monetary policy are reviewed. Part III goes on to examine the evidence available in published studies on the demand for various monetary aggregates concerning the appropriateness of that choice. Part IV examines the evidence from "reduced form" and causality studies. In Part $V$ the results of some new causality studies are presented. These provide direct answers to the questions posed above. As is well known, although causality tests are capable of providing guidance on causal ordering (or exogeneity) they are not substitutes for structural models. Furthermore, the simplest causality tests (those used in this paper) do not provide, as a by-product, reliable estimates of the parameters of transfer functions from policy instruments to policy targets. Although this paper does not present a structural model interpreting in detail U.K. monetary policy experience in the 1970 s it does (Part VI) examine alternative interpretations of causality relations found. Part VII presents a sumary and conclusions concerning future research and policy. The main conclusions are simple to state and worth anticipating. They are:

i) under flexible exchange rates, sterling $M 3$ causes inflation;

ii) neither $M$ nor the monetary base cause inflation under $f$ lexible exchange rates;

iii) none of the three monetary aggregates (sterling $M 3$, $M 7$, monetary base) causes reaI GDP;

iv) the public sector borrowing requirement does not cause sterling $M$ growth;

v) under fixed exchange rates, the price level and real GDP cause ster ling $\mathrm{M} 3$; 
vi) under fixed exchange rates, the foreign price level causes both the monetary base and the domestic price level, resulting in the appearance of a feedback relationship between domestic prices and the monetary base.

A11 these statements are, of course, subjected to caveats: they are based on bivariate, and in some cases trivariate, Granger (1969) causality tests and are conclusions reached at the 5 percent significance level. The term "causality" used without qualification through the paper means Granger-causality and is not meant to imply causality in any other sense.

II. BANK OF ENGLAND'S RATIONALE FOR TARGETING ON \&M3

The gradual emergence, through the 1970 s, of sterling M3 growth targets required the acceptance of two propositions: first, money matters and second, sterling $\mathrm{M} 3$ is money (or at least is the best empirical counterpart of the theoretical concept of money). This is not a suitable place for an extensive review of the arguments concerning the first of these questions. It is sufficient to note that the Bank of England's view (treating anything published in the Bank of England Quarterly Bulletin as representing the Bank's view) at the outset of the 1970s was clearly one which attached an important role to monetary aggregates (see especially Goodhart and Crockett (1970)). It is the second proposition; namely that sterling $M 3$ is money that will be addressed. That there is a problem of choice is evident from casual inspection of the time series set out in Figure 1. That figure shows the growth rates of four monetary aggregates, sterling M3, sterling M3 defined more broadly to include sterling deposits of non-residents (labelled sterling $\left.\mathrm{M}^{*}\right)$, $M 1$ and the monetary base (MB). It is evident that the exclusion of non-resident holdings of bank deposits in the official sterling M3 makes little difference to the growth rate of that broad aggregate. Thus, 
there are effectively three aggregate growth rates to be compared. By inspection it is immediately obvious that the growth rate of $M B$ is almost a mirror image of that of $M 1$. The monetary base growth rate follows that of M1 more closely than it does that of $M 3$, but is not well correlated with either of these two aggregates. ${ }^{2}$ It is evident then, from this inspection of the facts about growth rates of the alternative monetary aggregates through the $1970 \mathrm{~s}$ that a serious choice problem exists. It cannot be a matter of indifference as to which of the aggregates is to be treated as the intermediate monetary growth target. Let us turn now to examine how the Bank of England made the choice amongst these aggregates and came down in favor of sterling M3.

The most comprehensive evaluation and appraisal of this choice problem and justification for the choice of $\mathrm{M} 3$ was presented by the Deputy Governor of the Bank in a speech given to the Lombard Association in April 1973 entitled "Does the Money Supply Really Matter?" ${ }^{3}$ In that speech, the Deputy Governor noted that $M I$ and $M 3$ were not the only possible aggregates for monetary targeting but also noted that they each told a different story concerning the stance of monetary policy. At that time, the monetary base was hardly ever mentioned--at least in official circles--in the United Kingdom. Other aggregates, such as M2 (discontinued in 1972) and broader aggregates as well as variants on $M 1$ and $M 3$ were possible candidates for selection as the monetary target. The Deputy Governor went on to state the criteria used by the Bank in choosing an aggregate. First, the aggregate needs to be a variable for which there is an "availability of adequate statistical information...for a long enough period in the past to allow its behavior to be studied in relation to other developments in the economy." (p. 195): second, "the need to find, from the se studies, reasonably stable relationships between our chosen monetary aggregate and other variables such as the national income and levels of interest rates." (p. 195). Only if both of 


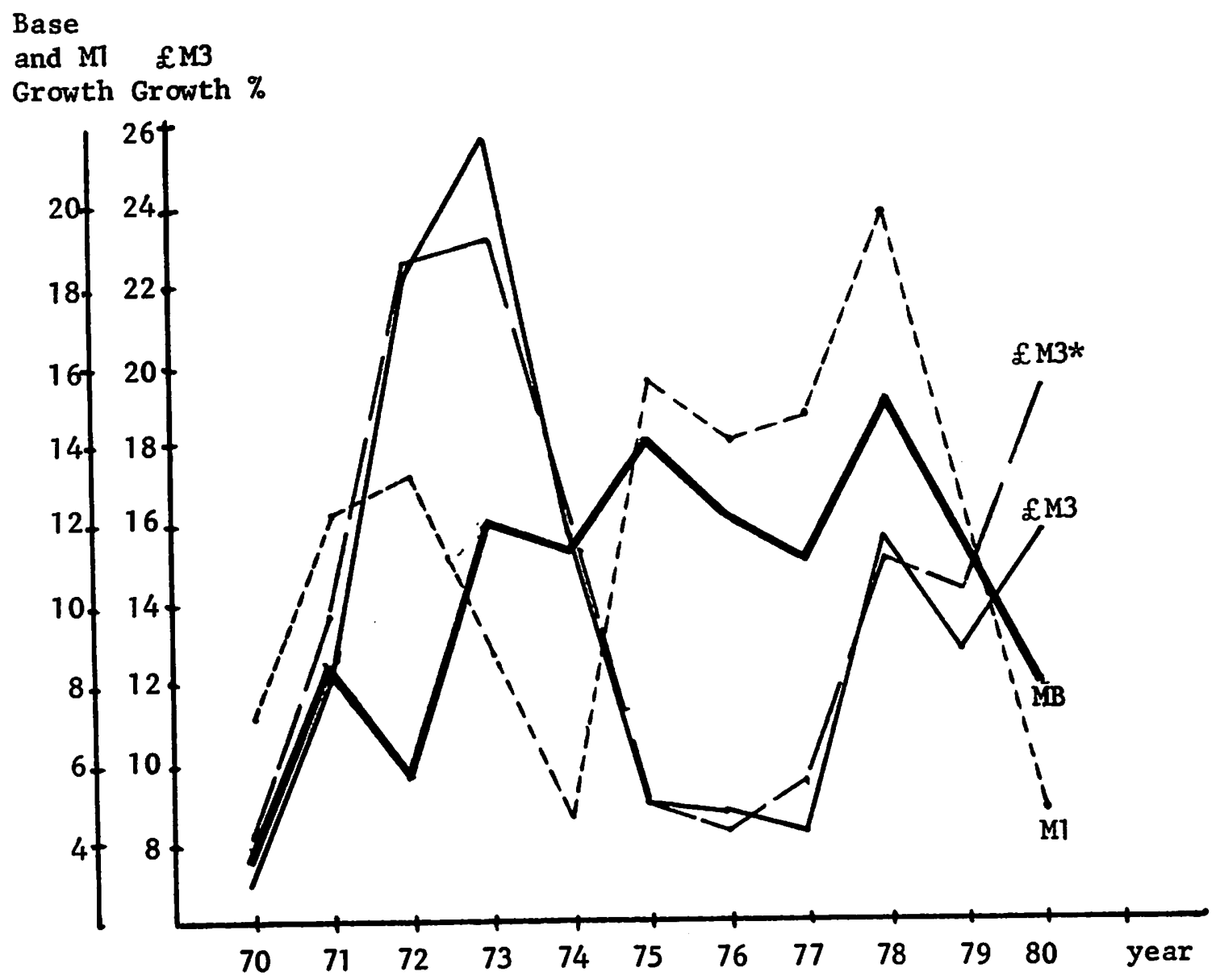

Figure 1

Money Supply Growth Rates

Source: See appendix. 
these criteria were satisfied by a monetary aggregate would that aggregate be useful either as an objective instrument or indicator of policy. The Deputy Governor went on to say that "partly because it is a well-established and long-running statistical series, most of the work that we have done in the Bank to study these relationships has been with M3...". (p. 195), and referred to the work of Goodhart and Crockett (1970) and Price (1972). The question of whether or not M1 might be potentially more useful than M3 was explicitly addressed and rejected primarily on the grounds that "estimates of Ml were inherently of poorer quality than those for M3... and monthly figures of $M 1$ have been available in their present form for little more than a year." (p. 198).

A further pronouncement by the Bank concerning the choice of M3 came much later in the Green Paper Monetary Control (Cmmd 7858, HMSO, London, March 1980) in which the use of M3 was justified primarily on the grounds that it was well understood in the financial markets.

To summarize the Bank's view; M3 was chosen as the relevant monetary aggregate for two reasons: first, because there existed a long run of reliable time series data on that aggregate and second, because studies of the relationship between that aggregate and income and interest rates established a relationship sufficiently reliable for the Bank to feel that they could exploit it for policy purposes. Although the Deputy Governor was not explicit in what precisely he meant by the behavior of the aggregate "in relation to other developments in the economy" the work that he cited examined both the properties and stability of the demand functions for alternative aggregates and "reduced form" relations between alternative aggregates and GDP and industrial output. It is of some interest to examine the evidence 
provided by those studies and others that were available at the beginning of the decade and also to see how the evidence evolved through the 1970s. This is the task of the next two sections, the first of which looks at the evidence from the demand for money functions studies and the second of which examines the "reduced forms" and subsequent causality tests.

III. EVIDENCE FROM DEMAND FOR MONEY STUDIES

At the beginning of the 1970 s there were very few econometric studies of the demand for money function in the United Kingdom. (For a survey of what was available, see Goodhart and Crockett, 1970.) The pioneering work of Kavanagh and Walters (1966) using annual data from 1880 to 1961 as well as Laidler and Parkin (1970) using quarterly data for 1953 to 1967 studied only broad money specifications and therefore are of little assistance in addressing the question posed here. Douglas Fisher (1968) using quarterly data from 1955 to 1967 did, however, study both broad and narrow formulations. There was little to choose between these two forms although the narrow might be marginally preferred over the broad on the grounds that, on the specifications used by Fisher, interest elasticities in the broad equations were not significantly different from zero.

The first careful comparison of demand functions using alternative aggregates was that by Goodhart and Crockett (1970). They used quarterly data from 1955 to 1969 and examined demand functions for M1, M2, and M3. On the basis of their reported estimates it is very hard to choose amongst the alternatives. In terms of goodness-of-fit, conformity of estimated coefficients to a priori predictions of theory as well as autocorrelation properties of the residuals, all look very similar. Even different forms 
of the demand function, whether or not a lagged dependent variable is included, whether or not short run degree one homogeneity in the price level is imposed, whether the equation is specified in per capita or aggregate terms, the same basic message emerges when comparing the different aggregates. On the basis of work performed and published in the beginning of the decade, there was simply no decisive resolution of the question as to which monetary aggregate would be the most appropriate for monetary target purposes.

The first demand for money study which seemed to tilt the scales somewhat towards $M 3$ was that by Price (1972). This study attended to the shapes of the lag distributions on the variables in the demand function in a more thorough way than hitherto. Specifically, different lag profiles were allowed for on the response of the demand for money to real income, the price level, and interest rates. Using these more general formulations, all the definitions employed fitted the data remarkably well. There is however one feature of the Price results which would tend to favor M3 over M1. This is the estimated long-run elasticities of the response of nominal money to the price level (reported in Table E on page 51). A priori, of course, they should be unity. Only in the case of $M 3$ (using a long-term interest rate) is the longrun elasticity estimated to be anywhere near unity. For M1 and $M 2$ (on both short and 1ong rates) and for M3 (on short rates) these 1ong-run elasticity estimates are somewhat wild. A further factor tending to favor M3 is the fact that data are available disaggregating M3 between persons and corporations. This enables different lag structures to be specified for these two aggregate groups of agents. Still better fitting demand functions emerge when this disaggregation 
is allowed for. These results reported by Price seem to be the basis for reasons presented by the Deputy Governor in his 1972 Lecture for preferring M3. The Bank of England's next effort in studying the demand for money function was that by Graham Hacche (1974). Hacche began by examining quarterly demand functions estimated on data for 1963(4) to 1971(3). Reporting the "best" equation for each of the aggregates (MI, M3, M3 personal, and M3 corporate) he showed that, at least on the basis of the standard error of the equation, M3 fitted the data better over that sample period than MI . Both had the same autoregressive properties (AR1) and both yielded long-run income elasticities which, although not entirely implausible, stretched plausibility somewhat each being below a half. Nevertheless, on the basis of that sample, M3 was marginally better than M1. Hacche went on to use the estimated equations to forecast out of sample from 1971 (4) to 1974(1). This forecasting exercise produced significant under-predictions by the M3 equation in eight out of the ten quarters forecasted. The MI equation significantly underpredicted only two of the ten quarters. The equations were re-estimated starting in 1963(4) and running up to 1972(4) with an "own rate" of interest included in the M3 equation. After performing what at least reads like a fairly heavy data mining operation (see pp. 294-95) to establish the best form in which to enter and measure the "own rate", Hacche was able to establish demand functions which fitted the sample period remarkably closely and again for which the M3 equation had a smaller standard of error estimate than $M 1$, had similar autoregressive properties in the residuals and had a more plausible long-run income elasticity than that found for the shorter sample. Again, however, when using the new equations to forecast out of sample, the MB equation performed badly relative to the Ml equation. 
The other major study of the demand for money in the United Kingdom published in the middle of the decade was that by Michael Artis and Mervyn Lewis (1976). Their work confirmed the instability found by Hacche in the demand for $M 3$ function and also confirmed Hacche's finding that the M1 function, although failing a Chow-Fisher test, displayed less instability than the M3 function. Indeed, according to the Artis and Lewis results, as the sample is extended through the $1970 \mathrm{~s}$, the Ml function tends to revert to that estimated for the 1960 s while the M3 function diverges even further. 4 Artis and Lewis' proposed resolution of the apparent instability of the demand for money functions is the hypothesis that the quantity of money held is not an equilibrium quantity and that the economy is, with varying degrees, "off" its demand for money function. A partial adjustment of income and prices rather than of real money holdings is proposed. As an empirical matter this alternative adjustment hypothesis produces a close tracking of the data through the 1970s for both $M 1$ and $M 3$. Whilst it is of some importance to address the question as to whether the Hacche or Artis-Lewis or some other resolution of the instability in the demand for money function in the 1970 s is correct, it is not an issue which bears on the problem being dealt with here. 5 Whether Hacche, Artis and Lewis, or some other hypothesis is accepted as explaining those instabilities, it is clear that, by the middle 1970s, a fairly solid body of evidence was emerging that reversed the earlier findings and pointed to the conclusion that M3 was of little use as the monetary aggregate for policy targeting purposes and that, on the basis of the estimated demand functions at least, imperfect though it may be, M1 was the best available aggregate. 
The most recent study of the demand for money in the United Kingdom seems to have reversed the conclusion. The work in question is an exceptionally thorough investigation by Grice and Bennett (1981). This study finds that it is possible to account for variations in real sterling M3 with greater precision than for $M$ or for the broader private sector liquidity aggregates (PSL1 and PSL2). Impressive though this recent study is, it does leave some serious puzzles unresolved. The demand function for sterling $M 3$ estimated by Grice and Bennett has an impressive fit. Its standard error is a mere one half of a percent. It also displays homogeneity of degree one in the price level and, in the steady-state, in wealth. Its steady-state income elasticity is close to $1 / 2$. It may be felt that this number is a little bit too low in view of the fact that sterling $\mathrm{M} 3$ is a broader aggregate than just transactions balances. Nevertheless, all of the above-noted features of the demand function are well in line with the predictions of all standard theories. The puzzles in the Grice/Bennett sterling M3 demand function concern interest rates and unexplained variations in movements in the aggregate. First, according to their results, the own interest rate effect is perverse. A rise in the rate of interest on sterling $M 3$ assets will lead to a significant drop in the demand for sterling M3. Second, the foreign rate of interest is also perverse, significant and quite strong. The only interest rate effect that is not perverse is the differential in the return on sterling $M 3$ and gilt-edged securities. That effect however is, in numerical terms, exceedingly small. Overa11, these interest rate results seem badly out of line with any reasonable priors. The margin of substitution between the least liquid components of sterling $\mathrm{M} 3$ and the most liquid components of private sector wealth outside the 
sterling M3 net would seem, a priori, to be one displaying extremely high elasticity. That this has not been found raises serious questions about the appropriateness of the measures of opportunity costs employed as proxies for the true expected opportunity cost variables.

Unexplained shifts in sterling $M 3$ also have to be allowed for in the Grice/Bennett study in order to get the equation to fit properly and behave we11. One of these, simply given the name "crisis dummy" does nothing other than remove a large positive residual in 1976(3) and an equally large negative residual in $1976(4)$. There is also a permanent shift in the demand function allowed for (identified as associated with Competition and Credit Control) after $1971(3)$.

A final feature of this study which has to be noted is the exceedingly complex lag structure employed and the greed of that lag structure in swallowing degrees of freedom. The "preferred" equation has 30 estimated parameters (from 64 observations). Eleven potentially non-zero parameters in the lag distributions are set equal to zero (on the basis of prior experimentation) so that, if one allowed for those coefficients, 41 degrees of freedom would be consumed in the estimation process leaving 23 degrees of freedom. It perhaps would be surprising if a demand function could not be fitted to a particular historical episode with that degree of licence. Overal1, the Grice/Bennett study of the demand for M3 seems best regarded as a thorough and interesting description of the behavior of that aggregate over the 1960 s and 1970 s but not a very solid basis for the design and conduct of monetary policy. 
It is clear from the above review of the properties of estimated demand for money functions that strong dominance emerges of one aggregate over another. At the present time, it does appear as if the demand for EM3 can be better explained than the demands for other aggregates. That superiority is not, however, strong and is purchased at a high price in terms of the complexity of--and unresolved puzzles contained in--the $f \mathbb{M} 3$ demand function.

Whilst the stability of the demand function for a monetary aggregate is an important condition for the use of that aggregate as a monetary target, it is certainly not a sufficient condition. It is clearly of greater importance that the aggregate in question be capable of exerting some causal influence on the ultimate targets of macroeconomic policy. The literature which has addressed this question will now be examined.

IV. EVIDENCE FROM "REDUCED FORMS" AND CAUSALITY TESTS

The earliest attempt to establish the influence of money on real economic activity in the United Kingdom was the replication of the FriedmanMéiselman U.S. study by Barrett and Walters (1966). The results were generally interpreted as favoring the hypothesis that money has some role to play in the process generating income, but were inconclusive as to the precise nature of that role. Further, that study used only one broad definition of the money stock and therefore was not able to shed light on one of the central questions of interest here. The first quarterly study (covering the period 1958-1967) by Artis and Nobay (1969) did examine the role of alternative definitions of money in a fairly comprehensive way. Four 
measures of the money stock (narrow money, broad money, narrow base, and broad base) as well as bank advances were employed. Using a stepwise regression procedure, Artis and Nobay were able to explain a high percentage of the variance of the change in nominal income using the broad money supply, bank advances and a fiscal policy variable. This finding, in favor of the broad over the narrow monetary aggregate, was examined further by Goodhart and Crockett (1970). They regressed two alternative measures of real output (real GDP and industrial production) on current and lagged (up to seven quarters) values of three alternative definitions of the money supply, M1, M2, and M3. They concluded that "M3 appears to give the best explanation of changes in output whichever output measure is used" (p. 197). They reached that conclusion by comparing standard errors of three alternative regressions using the three alternative definitions of money stock with the constant suppressed. If the constant is included in the regression (p. 198) M appears to give the best explanation for real GDP while M3 gives the best for industrial production. In any event, the results are very close to each other. More recently, Matthews and Ormerod (1978) gave a precise replication of the Anderson and Carlson (1970) St. Louis equation. They used four definitions of the money supply (the monetary base, M1, M3, and the International Financial Statistics definition of M). Using quarterly data from 1964(2) to 1974(4) with Almon lags their empirical results for the United Kingdom were almost identical to those that Anderson and Carlson had found for the U.S. They also discovered that the model performed well in within-sample dynamic simulations. All four definitions of money worked tolerably well though the monetary base performed the best. Further, regardless of the 
monetary variable used, the sum of coefficients on the fiscal variable was never significant. These results were not, however, robust with respect to a seemingly innocuous specification change. The switch to Competition and Credit Control which affected bankers' demand for monetary base was allowed for by entering a Competition and Credit Control dummy variable in the model. When this was done the significance of the money variables vanished in all cases, except for the monetary base.

Though these studies all reveal some interesting correlations, the hard inferences which may be made on the basis of them are few. None of the studies attempted to establish whether or not the monetary variables used had any causal influence upon output (real or nominal) or the price level. This is perhaps not surprising since an operational definition of causality was not available until after the work of Granger (1969) and no explicit formal tests had been conducted until the seminal contribution of Christopher Sims (1972).

Following Sims's work, which concluded that "the hypothesis that causality is unidirectional from money to income agrees with the U.S. postwar data" (p. 540), Williams, Goodhart and Gowland (1976) re-examined the United Kingdom data to see whether the same conclusions applied in that case. Those authors suspected that Sims's finding might not apply to the United Kingdom and for two reasons. First, the degree of openness of the United Kingdom economy is much greater than that of the U.S. and, their a priori prediction was that, with fixed exchange rates which prevailed for the entire period of the sample available, the money stock would be endogenous. Second, the U.K. monetary authorities' procedure for influencing 
the economy is one which operates upon the level and structure of interest rates. This would further lead to the prediction of an endogenous money stock. Using two series of the money supply, one approximating $M$ and the other M3, for the quarterly period 1958(1) to 1971 (3) and performing tests identical to those used by Sims (but with alternative pre-filters) the authors were able to reject all causality statements relating nominal income to broad and narrow money. The hypothesis that nominal income causes narrow money was, however, only narrowly rejected. Splitting nominal income between real income and the price level produced similarly negative results. In this case the proposition that narrow money causes the price level was the result that came closest to achieving the 95 percent level of significance. In a more recent Bank of England study by Enoch (1979), causality between money and prices and the exchange rate in the floating exchange rate period (1972 to 1977) was examined. Enoch found bi-directional causality amongst all his variables. In this case, however, "money" was domestic credit expansion and the price variables were export and import prices. Enoch did not explore causality between money and income.

A theoretical reconciliation of Sims's findings for the United States and those of Williams, Goodhart and Gowland was proposed by Putnam and Wilford (1978) in terms of the conventional monetary theory of the balance of payments. Their explanation also would be consistent with the finding of feedback in the later work of Enoch covering the flexible exchange rate period.

The studies reviewed so far used the Sims's test to search for causality. In the period since the publication of Sims's pioneering paper 
a great deal of analytical as well as simulation work has been done on alternative causality testing procedures. It appears, on the basis of this work, that the test proposed by Granger (1969) which is asymptotically equivalent to that of Sims is nevertheless to be preferred to the Sims's test on the grounds that the latter is sensitive to changes in the prefiltering scheme employed. (See Cuddington (1981), for a brief review of the literature on this and also Geweke, Meese and Dent (1982).) Some recent papers on money and causality in the United Kingdom have employed the Granger test.

The first of these by Mixon, Pratt and Wallace (1979) sought to test the Putnam and Wilford reconciliation of the findings of Sims on one hand and Williams, Goodhart and Gowland on the other. Splitting the $1962(1)$ to $1977(3)$ sample into a fixed exchange rate period (to $1970(4)$ ) a transition (to $1974(3)$ ) and a flexible exchange rate period (1974(4) on) they found that they were able to reject the hypothesis that U.S. money causes U.K. income for the fixed exchange rate period. They were able to reject the hypothesis for the transition to the flexible exchange rate period at the 95 percent level. These authors did not, however, test for the effects of domestic money in any of its variants. A similar causality test concerning money income in the United Kingdom is that by John Cuddington (1981). He re-examines the same fixed exchange rate period that featured in the original Williams, Goodhart, and Gowland study and uses only their narrow money definition. Using Granger tests, but searching for more intricate causality patterns, cuddington finds that the long-term United Kingdom interest rate is the only exogenous variable when employed in the series bi-variate causality tests along with nominal income, narrow money, and the balance of payments. The patterns of causality established in that 
study are that the long-term U.K. interest rate causes money, nominal income and the balance of payments while there is also a causal link running from income to money and the balance of payments. Cuddington interprets his findings as suggesting that the United Kingdom monetary authorities are exogenously controlling the long-term U.K. interest rate. An alternative interpretation of his results ${ }^{6}$ is that the long-term bond market in the United Kingdom is efficient and the bond rate follows a Martingale. That being so, it will appear as exogenous. This hypothesis is indistinguishable from Cuddington's--at least at the level of temporal aggregation employed. A further study, using daily data, 7 (Hilliard, 1979), whilst not providing confirmation for the efficient markets hypothesis, finds unidirectional causality from the change in foreign exchange reserve to the long-term interest rate and therefore casts further doubt on Cuddington's interpretation of his own results.

There has been a spate of studies on the relationship between money and prices coming out of The London Business School, The Treasury and the Bank of England in the past two years. The London Business School studies are closely related to each other and are by Holly and Longbottom (1980) and Beenstock and Longbott om (1980) and are summarized by Budd, Holly, Longbott om and Smith (1981). In these studies the relationship between sterling $M 3$ and wholesale prices is investigated. Holly and Longbottom employ four different procedures for testing for the causality relation between money and prices. These are the cross-correlation analysis of innovations (Wall (1974), Haugh (1976) and Pierce (1977)), the estimation of a multivariate transfer function (Wall (1974), Caines and Chan (1975)), the estimation of a one-sided AR model using Almon lags and finally the estimation of a onesided AR model using the model selection and testing procedures suggested by 
Mizon (1977), Davidson, et al (1978) and Hendry (1980). The cross-correlation exercises are inconclusive but the other three approaches lead these authors to the same broad conclusion. That conclusion is that sterling MB Grangercauses wholesale prices. The particular equation arrived at via the transfer function approach (and summarized in Budd et al) is one in which the rate of inflation depends upon the rate of growth of the money stock from five to fifteen quarters earlier, augmented with a fourth-order moving average in the error term. Results by other procedures are similar. The reader is informed that these results were "finally arrived at...after a considerable degree of experimenting". At the same time the authors find that prices cause money but with a much shorter lag. In fact, prices one quarter earlier Granger-cause the money stock. Again, this process has a fourth-order moving average error structure. Beenstock and Longbottom (1980) perform exercises quite similar to those of Holly and Longbottom. In their price reduced form equation, the money stock six and seven quarters earlier are the only ones that appear.

Although the London Business School workers interpret their results as evidence in favor of Granger-causality running from sterling $M B$ to wholesale prices, there do appear to be serious difficulties in the way of accepting that conclusion too readily. First, the estimated lags seem to be quite incredible. Acceptance of these results makes it necessary to accept the proposition that money does not begin to have effects on prices until more than one year has elapsed. The effects then run out to four years. (Alternatively, in the case of Beenstock and Longbottom, the effects are all concentrated at the one-and-a-half to two year point.) It 
is worthy of emphasis that these are not propositions about average lag lengths in the relationship between money and prices. They are propositions about the first impact of money on prices. Whilst it would be widely believed that the effects of money on prices would be variable and long drawn out it seems to be stretching credibility too far to suppose that no effects begin until more than a year has elapsed. A further reason for caution in accepting the conclusions of these studies arises from the limited role which previous inflation was allowed to play in generating current inflation. One wants to know what the contribution of previous monetary growth is after allowing previous inflation to do all the work that it is capable of in contributing to an explanation of variations in current inflation.

The Treasury contribution to this literature is the work of Simon Wren-Lewis (1981). This study uses retail prices as the measure of inflation and sterling $\mathrm{M} 3$ as the measure of money. It begins with the most general reduced form equation for prices that can be estimated and then successively restricts the equation until the minimum standard error model has been found. The starting point is an equation that contains 14 lags of the inflation rate and 13 lags of the growth rate of sterling M3. That equation has 13 degrees of freedom. Successive restrictions are applied until the minimum standard error reduced form is achieved. This is an equation in which the growth rate of the money supply appears with lags of $1,4,6,10,11,12$ and 14 quarters and the rate of inflation with lags of 1,6 and 9 quarters together with the price level with lags of 1 and 12 quarters. In addition to "money on $1 y^{\prime \prime}$ reduced forms, Wren-Lewis also estimates reduced forms with other variables such as real government expenditures, wealth, indirect taxes, foreign exchange and domestic credit expansion, oil prices, food prices, world 
money and incomes policy.

Like the London Business School work, that of Wren-Lewis is hard to interpret in terms of its implications for causality. There is no question that this study is one of the most comprehensive and thorough descriptive treatments of the relationship between retail prices and a variety of potentially important causal variables. The methodology employed however, does not seem to permit clean inferences concerning the causal influence of money (or the other variables). Further, like the London Business School work, most of the action from money is coming with an impact that implies an unbelievably long lag in the relationship between money and prices.

The Bank of England work in this area is that by Terrence Mills (1981). Instead of performing causality tests however, Mills employs the information approach of Tinsley, Spindt and Friar (1980), following Theil (1967). Essentially, the question asked by Mills concerns the loss of predictive power (for predicting both the price level and nominal income) by using aggregates rather than sub-aggregates of money. The study focuses on the monetary base, $M 1$, and then broader aggregates going all the way through to private sector liquidity. The conclusion of that study is that "restricting attention to anything less than the broadest monetary aggregate currently available involves a considerable amount of information loss" (p. 9). Because of its different statistical methodology it is not easy to see exactly what the connection is between these findings of Mills and those of the causality studies. 8

It is difficult to provide a succinct summary of the diversity of findings of the causality tests that have been performed on United Kingdom data. We have already expressed our skepticism concerning the work of the London Business School and Treasury as far as any conclusions about causality are 
concerned. That is not to say that this work does not provide extremely valuable characterizations of the time series. Those studies are telling us quite clearly that if we seek to characterize the time series on inflation and money as displaying a Granger-causal relation going from money to prices then we must accept the conclusion that money only begins to have its effect on prices after a lag of about a year and a half. The studies do not seem to tell us that we may only consider the time series behaviour of prices in this light and they do not provide us with an unambiguous demonstration of the contribution of lagged money to prices over and above the contribution of lagged prices themselves.

Turning to the earlier work of Williams, Goodhart and Gowland, their finding of independence between both broad and narrow money and income are clearly in conflict with Cuddington's result that income causes narrow money. The most natural interpretation of that pair of results is that Cuddington has found the "truth" and that the earlier study employed a less reliable test. The finding of full simultaneity between money (defined as $D C E)$, the exchange rate and international trade prices is also presumably suspect on the same grounds. The conflicting findings between Hilliard and Cuddington are less easily resolved since, although Hilliard uses a less reliable test, the employment of daily data presumably gives greater precision to the search for causality. This last conflict, however, is not of central relevance to the major point of inquiry of this paper.

To the extent that the older studies reviewed above do shed light on the questions of interest here, they point in a strongly negative direction concerning the potential role of money as an influence on income and prices. This conclusion is enhanced by an aspect of that early Bank of England St. Louis-type study (Goodhart and Crockett, 1970) reviewed above. Although only briefly referred to, those authors came very close to performing a Granger 
test on the causality relation between $M 7, M 2$ and $M 3$ on the one hand and real income on the other. They estimated equations which included a lagged value of income as well as those including only a distributed lag of money. They reported that "using first differences of the data, no role for money could be detected in the estimated form of [the equation that included the lagged dependent variable]. As a result attention was concentrated on [the equation that excluded the lagged dependent variable]" (p. 197). Although not quite a formal Granger test, the authors clearly performed such a test in an informal manner. That result, although generated using a data base that ended in the $1960 \mathrm{~s}$, has still not been convincingly overturned by any published causality results known to us though we recognize that the LBS and Treasury studies could be interpreted as so doing. In an attempt to provide clearer evidence on the causality questions posed at the beginning of this paper we now turn to describe and report a series of tests that we have performed.

V. NEW EVIDENCE FROM CAUSALITY TESTS

The exercise conducted and reported in this section attempts to establish the causal ordering of money (on various definitions), real income and prices. Specifically, the question addressed is: Do any definitions of money cause either the price level or real income? If so, which one(s)? If there is any causality, is it unidirectional or are there feedback relationships amongst the variables? Our method of answering these questions is to use the procedures for testing for causality suggested by Granger. That method involves running regressions of a given variable (say A) on its own lagged values and on lags of some other variable (say B) 
and establishing whether past values of B significantly lower the mean square error of $A$. The procedure is then reversed to see whether past $A$ lowers the mean square error of B. If past B improves our forecasts of $A$ but past $A$ does not improve forecasts of. $B$, then $B$ is said to cause $A$. If $B$ does not contribute to forecasts of $A$, then $B$ does not cause $A$. If $B$ improves our ability to forecast $A$ and if $A$ improves our ability to forecast $B$, then there is a feedback relation amongst the variables.

Two preliminary matters had to be dealt with before we could proceed to perform Granger-causality tests. The first of these concerns the length of time lag to be employed and the second concerns the form in which to enter the variables.

The lag lengths on the dependent variable and on the potential causal variable were fixed at four quarters. This lag length was imposed on the basis of a good deal of prior experimentation by others. First, in Sims's (1972) study ${ }^{9}$ of the United States, the implied lag length on the causal or monetary variables were four quarters. Secondly, in an explicit test of four versus eight quarters, and using United Kingdom data, Cuddington (1981) was not able to find any significant increases in explanatory power from increasing the lag length above four quarters. 10 Thirdly, in a study which experimented with lags of up to thirteen quarters (and referred to earlier), Wren-Lewis (1981) was not able to reject the hypothesis that the coefficients on all lags above four was insignificant. ${ }^{11}$ Finally, Holly and Longbottom (1980) found from a univariate ARMA analysis that fourth-order autoregressions of inflation and money growth were sufficient to achieve white residuals. ${ }^{12}$ All of this pre-testing by other scholars points strongly to the imposition, a priori, of a fourth-order lag on the processes being 
investigated. This is the approach that was adopted and no data mining or subsequent experimentation was done in the study reported here.

We recognize that a maximum lag of four quarters imposes strong a priori restrictions. In particular, we are maintaining the hypothesis that, if money causes prices (or vice versa), then those causal influences will become apparent within one year. We are not of cour se claiming that the lag profile relating money to prices is one that disappears after one year. The presence of four lagged price terms in the price equation (and equivalently of four lagged income terms in the income eequation) permits the overall distribution to be infinite and the mean lag to be determined by the particular pattern of coefficients estimated.

We also recognize that in imposing a maximum lag of four quarters we are ruling out, a priori, the preferred specifications of the money-prices transfer functions/reduced-forms, offered by the London Business School and by Wren-Lewis. We do not claim that the data reject their preferred formulations. They emphatically do not. We do claim, as do these scholars, that the data do not reject our prior restrictions on lag length. Further, we claim that the lag lengths implied by these other studies are simply incredible. Lags that start after more than one year and run to four years on monetary causal variables do not make any sense to us on the basis of any known theory. It is curious in fact that the only way in which Wren-Lewis seeks to defend such lags is by invoking the structure of large scale econometric models as if they represented data, arguing that since such models exist, the lags must be long and complicated. That author does notice that if agents possess some rationality, the lags might be shorter but he dismisses that possibility as Iudicrous. He further recognizes that "short maximum lags can still produce average lags of considerable length". 13 We are at a loss to understand the 
rationale for Wren-Lewis' methodology. We accept that he has found a description of the data but we do not believe that he has shed any interesting light on the causal relations between money and prices.

Let us now turn from our defence of our a priori restrictions on lag length to deal with the second preliminary matter--that of the form in which to enter the variables.

Perhaps the most natural specification for investigating the causal relations between money income and prices is one that defines all the variables as first differences in the logarithms. Such transformations, representing growth rates, will be free from the nonstationarities that arise in the levels of time series variables. Additionally, however, there may be time trends and certainly in seasonally unadjusted data there will be seasonal influences. The specification that suggests itself therefore is:

$$
\begin{aligned}
\Delta z_{t}=\alpha_{0} & +\alpha_{1} t+\alpha_{2} s_{1 t}+\alpha_{3} s_{2 t}+\alpha_{4} s_{3 t}+\sum_{i=1}^{4} \alpha_{4+i} \Delta z_{t-i} \\
& +\sum_{i=1}^{4} \alpha_{8+i} \Delta m_{t-i}+u_{t} \\
\Delta m_{t}=\beta_{0} & +\beta_{1} t+\beta_{2} s_{1 t}+\beta_{3} s_{2 t}+\beta_{4} s_{3 t}+\sum_{i=1}^{4} \beta_{4+i} \Delta m_{t-i} \\
& +\sum_{i=1}^{4} \beta_{8+i} \Delta z_{t-i}+v_{t}
\end{aligned}
$$

where

$$
\begin{aligned}
z_{t} & =\log y_{t} \text { or } \log p_{t} \\
m_{t} & =\log (\operatorname{MM} 3)_{t} \text { or } \log (M T)_{t} \text { or } \log (M B)_{t} \\
t & =\text { time trend } \\
s_{i t} & =\text { seasonals } \\
p & =\text { the GDP deflator } \\
y & =\text { real GDP. }
\end{aligned}
$$


An alternative specification would be:

$$
\begin{aligned}
& z_{t}=\alpha_{0}+\alpha_{1} t+\alpha_{2} s_{1 t}+\alpha_{3} s_{2 t}+\alpha_{4} s_{3 t}+\sum_{i=1}^{5} a_{i} z_{t-i} \\
&+\sum_{i=1}^{5} a_{5+i} m_{t-i}+u_{t} \\
& m_{t}=\beta_{0}+\beta_{1} t+\beta_{2} s_{1 t}+\beta_{3} s_{2 t}+\beta_{4} s_{3 t}+\sum_{i=1}^{5} b_{i} m_{t-i} \\
&+\sum_{i=1}^{5} b_{5+i}{ }^{z} t-i \\
&
\end{aligned}
$$

where the variables are as defined above but are now expressed in level form. Clearly, if

$$
\begin{aligned}
& \sum_{i=1}^{5} a_{i}=\sum_{i=1}^{5} b_{i}=1 \\
& \sum_{i=1}^{5} a_{5+i}=\sum_{i=1}^{5} b_{5+i}=0
\end{aligned}
$$

then (1) and (2) are identical to (3) and (4). If the restrictions embodied in (5) and (6) are not valid, then (3) and (4) would seem preferable to (1) and (2) since they are more general. There are, however, two potential problems with (3) and (4). First, because the variables are entered as levels, they are dominated by their upward time trends. These nonstationarities pose severe problems for statistical inference. Second, being dominated by their trends, the levels of the variables are highly collinear. Since we are entering up to five lags of the levels, the multicollinearity amongst the variables is likely to be substantial. This will lower the power of the F-tests that we wish to perform. We shall return to these matters sub sequent ly. 
Before turning to a description of the tests that we performed and an assessment of their results, there is one final preliminary matter that needs to be dealt with. Although the time series methods that we are employing impose a minimum of a priori restriction on the data, there is one prior which is so strong that to ignore it would be likely to lead to trouble. This concerns the role of the exchange rate regime. We do not expect time series processes relating money to income or prices (and vice versa) to be invariant across fixed and flexible exchange rate regimes. The United Kingdom moved from fixed rates to flexible rates at about the half-way mark in the sample of data available to us. We decided, therefore, to work with two subsamples. One runs from 1964(2) to $1972(3)-$-fixed exchange rates--and the second from $1972(4)$ to $1980(4)--f l e x i b l e$ exchange rates.

Let us now turn from these preliminary matters to examine the results of the tests performed. First, we estimated equations of the forms of both (1) and (2) and (3) and (4) using three alternative definitions of money (the monetary base, MI and sterling $M 3$. We tested the overidentifying restrictions (5) and (6) implied by the first difference formulation (1) and (2). The results of these tests are summarized in Table 1. (An alternative likelihood ratio test not reported directly in Table 1 gave almost exactly the same results.) It is clear from the results in Table 1 that the first difference restrictions are rejected on the basis of the F-tests shown in a large fraction of cases. On this basis, it may be felt that the levels formulation (equations (3) and (4)) is more appropriate. We have difficulty in accepting that conclusion for reasons alluded to before. Both the nonstationarity of the variables in equations (3) and (4), together with the fairly high multicollinearity, make the F-test one of low power. It seems to us therefore that 
Table 1

Tests of the First Difference Restrictions

\begin{tabular}{|c|c|c|c|c|c|c|}
\hline \multirow[t]{2}{*}{$\underline{\text { Equation }}^{(a)}$} & \multicolumn{2}{|c|}{$\begin{array}{r}\text { Fixed Exchange Rate } \\
(1964(2)-1972(3))\end{array}$} & \multicolumn{2}{|c|}{$\begin{array}{c}\text { Flexible Exchange Rate } \\
(1972(4)-1980(4))\end{array}$} & \multicolumn{2}{|c|}{$\begin{array}{l}\text { Combined Samples } \\
(1964(2)-1980(4))\end{array}$} \\
\hline & $\begin{array}{l}\text { Degrees of } \\
\text { Freedom }\end{array}$ & $\mathrm{F}^{(\mathrm{b})}$ & $\begin{array}{l}\text { Degrees of } \\
\text { Freedom }\end{array}$ & $F^{(b)}$ & $\begin{array}{l}\text { Degrees of } \\
\text { Freed om }\end{array}$ & $\mathrm{F}^{(\mathrm{b})}$ \\
\hline LM3 & 1,23 & 1.00 & 1,24 & $5.49^{(c)}$ & 1,52 & 3.47 \\
\hline$£ \mathrm{M} 3 / \mathrm{p}$ & 2,18 & $6.91^{(c)}$ & 2,19 & 2.84 & 2,47 & $3.26^{(c)}$ \\
\hline fM3 /y & 2,18 & $5.04^{(c)}$ & 2,19 & 1.79 & 2,47 & $3.40^{(c)}$ \\
\hline $\mathrm{p} /$ \&M3 & 2,18 & 2.18 & 2,19 & $8.27^{(c)}$ & 2,47 & $3.78^{(c)}$ \\
\hline $\mathrm{y} / \mathrm{fM} 3$ & 2,18 & 3.18 & 2,19 & 1.69 & 2,47 & $3.21^{\text {(c) }}$ \\
\hline Ml & 1,23 & 0.23 & 1,24 & $5.07^{(c)}$ & 1,52 & 3.20 \\
\hline $\mathrm{M} 1 / \mathrm{P}$ & 2,18 & $3.58^{(c)}$ & 2,19 & 1.93 & 2,47 & $4.17^{(c)}$ \\
\hline $\mathrm{Ml} / \mathrm{y}$ & 2,18 & $3.95^{(c)}$ & 2,19 & 2.42 & 2,47 & 1.84 \\
\hline $\mathrm{p} / \mathrm{M} 1$ & 2,18 & 0.44 & 2,19 & $3.90^{(c)}$ & 2,47 & 2.82 \\
\hline $\mathrm{y} / \mathrm{Ml}$ & 2,18 & 2.91 & 2,19 & 1.25 & 2,47 & 1.53 \\
\hline MB & 1,23 & 2.79 & 1,24 & $5.36^{(c)}$ & 1,52 & 0.82 \\
\hline $\mathrm{MB} / \mathrm{p}$ & 2,18 & 1.85 & 2,19 & 2.56 & 2,47 & $4.44^{\text {(c) }}$ \\
\hline $\mathrm{MB} / \mathrm{y}$ & 2,18 & 0.74 & 2,19 & 3.21 & 2,47 & 0.69 \\
\hline $\mathrm{p} / \mathrm{MB}$ & 2,18 & $8.34^{(c)}$ & 2,19 & 3.50 & 2,47 & 2.69 \\
\hline $\mathrm{y} / \mathrm{MB}$ & 2,18 & 2.06 & 2,19 & 2.29 & 2,47 & $6.41^{(c)}$ \\
\hline $\mathrm{p}$ & 1,23 & 0.15 & 1,24 & $6.84^{(c)}$ & 1,52 & 1.80 \\
\hline $\mathrm{y}$ & 1,23 & $4.35^{(c)}$ & 1,24 & 4.09 & 1,52 & 1.09 \\
\hline
\end{tabular}

Notes :

(a) Based on estimation of equations of the form of (1)-(4) in text. The first named variable is the dependent variable and its lags together with lagged values of the second named variable (as well as a constant, seasonal dummies and time trend) are the right-hand side variables . Where only a single variable is named this indicates the estimation of (1)-(4) with the $z_{t}$ or $m_{t}$ variable omitted.

(b) Critical values of $F_{.05}$ are: $\{1,23\}=4.28 ;\{1,24\}=4.26 ;\{1,52\}=4.03$; $\{2,18\}=3.55 ;\{2,19\}=3.52 ;\{2,47\}=3.17$.

(c) Indicates rejection of the first difference restrictions at the $5 \% 1$ level. 
there is good reason to use the first difference formulation even though there is some doubt as to whether or not the data reject it. The safest procedure seems to us to be one which examines causality using both the difference formulation and the level formulation set out above. The former has the advantage of working with stationary processes and with much less multicollinearity. The second has the advantage that it fits the data more closely. In what follows we shall therefore look at both levels and differences.

The central findings of the causality tests performed are summarized in Table 2. Results are given for both exchange rate regimes and for both the first difference and level formulation of the relationships. The first feature of the results that is apparent is the appearance of conflict between the first difference and levels formulations. According to the levels formlation, sterling M3 causes prices under flexible exchange rates and both prices and real GDP cause sterling $M 3$ under fixed exchange rates. In addition, $M$ causes real GDP and there is a feedback relationship between the money base and the price level under fixed rates. There are no other significant causal relations amongst these variables. According to the first đifference formulation there are no significant causal relations under flexible exchange rates and under fixed rates Ml continues to cause real GDP and the price level causes the money base. Let us probe these findings a little more deeply.

First, consider the fixed exchange rate regime. Here we are getting a clear message that $M$ and only $M$ causes real GDP. This comes through whether we use the difference or level formulation. On prices we are getting 


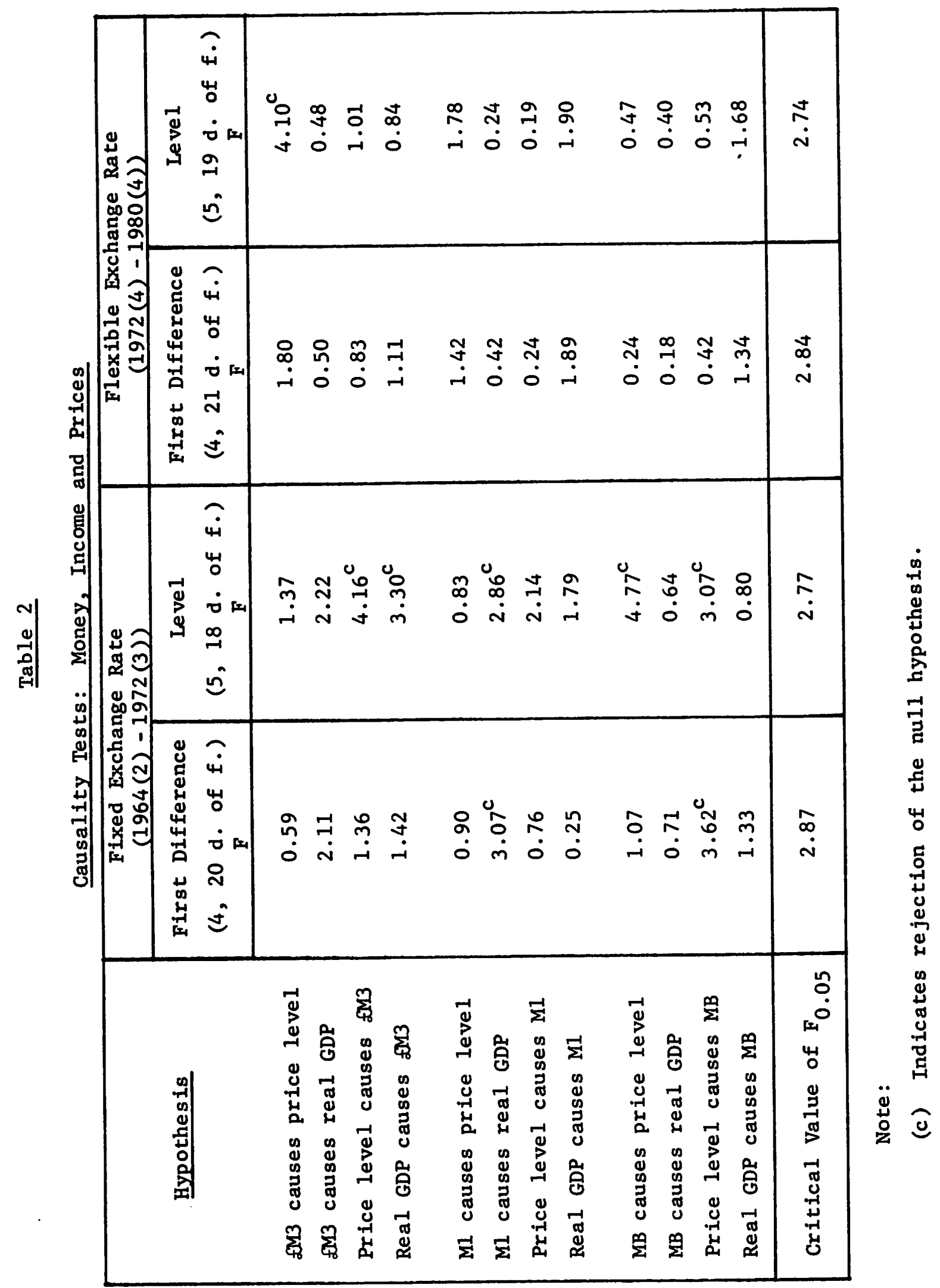


conflicting messages. Perhaps prices and real income cause sterling M3 and perhaps there is a feedback relation between the price level and the monetary base. The first difference and level formulations do not give the same conclusion however on those matters.

Let us first look at the M7 real GDP result a little more closely. This seems to be a strange finding in view of the fact that Ml does not appear to cause real GDP under flexible rates and it does not appear to have any price level effects. The fact that this result shows up only under fixed exchange rates raises the suspicion that there is some other third variable that needs to be controlled for that is giving rise to what is essentially a spurious finding. To check out this possibility, we looked at the trivariate causal relations between $M 7$ and real GDP together with a series of other variables (dealt with one at a time). The other variables examined were foreign prices, the balance of payments and the public sector borrowing requirement-as a proxy for fiscal policy. Controling for the public sector borrowing requirement and the balance of payments essentially leaves the results shown in Table 2 unchanged. Controlling for foreign prices however does not. Table 3 sets out the results of these tests. We find that, when controlling for foreign prices the result that M causes real GDP is reversed. We are now not able to reject the null hypothesis that M does not cause real GDP given the behavior of the foreign price level. There are no other causal relations among these three variables, though the nearest thing there is to a significant effect is from the foreign price level to MI. Whilst it is not possible, simply on the basis of tests of this kind, to unravel the full details of the relationships involved, we suspect that the appearance of MI causing GDP under fixed exchange rates (Table 2) arises from some common influence of rest of wor Id shocks on $M$ and domestic 
Table 3

M1, Real GDP and Foreign Prices under Fixed

Exchange Rates

(First Difference Form)

\begin{tabular}{|c|c|}
\hline \multicolumn{1}{|c|}{ Hypothesis } & $\begin{array}{c}\mathrm{F} \\
(4,16 \mathrm{~d} \text {. of f. })\end{array}$ \\
\hline M1 causes real GDP given foreign price level \\
M1 causes foreign price level given real GDP \\
Real GDP causes M1 given foreign price level \\
Real GDP causes foreign price level given M1 \\
Foreign price level causes M1 given real GDP \\
Foreign price level causes real GDP given M1 & 0.28 \\
\hline Fo.05 (4, 16) & 0.65 \\
\hline
\end{tabular}


economic activity. Although unresolved, we take it that the trivariate analysis of Table 3 dominates the bivariate results in Table 2 and leads to the conclusion that MI does not cause real GDP under fixed exchange rates.

The most puzzling feature of the fixed exchange rate results is the strong feedback relation between the monetary base and the price level. In order to explore that relationship further we also considered trivariate causal relations involving the same variables as those stated above. Again it was discovered that the foreign price level was a critical factor involved. The results of trivariate tests between money base, prices and foreign prices under fixed exchange rates are set out in Table 4. What those reveal is that the foreign price level is the dominant causal variable and that foreign prices significantly influence the monetary base. That causal relation is the only one apparent in Table 4. The price level however almost significantly causes the monetary base given the foreign price level. It is the failure to control for foreign prices that generates the appearance of feedback in Table 2. As before, it seems that this trivariate relationship dominates the bivariate relationship in Table 2 and leads to the conclusion that there is no feedback between money base and prices.

Interpreting the results in Table 2 with the aid of the additional tests reported in Tables 3 and 4 , leads to the tentative conclusion that there are no causal influences of domestic money (no matter how measured) on real GDP or the price level under fixed exchange rates.

Let us now turn to the flexible exchange rate results. Comparing the first difference and level formulations, there is no conflict except for the finding that sterling M3 causes prices under levels whilst there are no 
Table 4

Monetary Base, Prices and Foreign Prices

Under Fixed Exchange Rates

(Leve1s)

\begin{tabular}{|l|c|}
\hline \multicolumn{1}{|c|}{ Hypothesis } & $\begin{array}{c}\text { F } \\
(5,13 \mathrm{~d} \text { of f. })\end{array}$ \\
\hline MB causes price level given foreign price level \\
MB causes foreign price level given price level \\
Foreign price level causes price level given MB \\
Foreign price level causes MB given price leve1 \\
Price level causes MB given foreign price level \\
Price level causes foreign price level given MB & 1.31 \\
\hline Fo.05 (5, 13) & $5.41^{\mathrm{c}}$ \\
\hline
\end{tabular}

Note:

(c) Indicates rejection of the null hypothesis. 
causal relations at all under the first differences. We sought to explore whether or not there was any potential reconciliation between the conflicting MB price level results by looking more closely at the role of third variables in this relationship. We also examined the exogeneity of sterling MB with respect to a broader set of variables. Table 5 examines the second question--that of the exogeneity of sterling M3. Specifically, we examined whether or not sterling M3 was significantly influenced by foreign effects (foreign price level and balance of payments) or by the public sector borrowing requirement. We are unable to reject the null hypothesis in all cases and fairly decisively so in most. Thus, at least with respect to the set of variables being considered here, sterling $M$ is an exogenous variable.

Which, however, of the results concerning the effects of sterling M3 is correct? Does ster ling $M 3$ cause the price level or not? In an attempt to resolve this issue we explored, using first differences, the effects of ster ling M3 on domestic inflation when controlling for foreign prices, the balance of payments and the public sector borrowing requirement. The latter two variables did not change the results shown in Table 2. Controlling for foreign prices however dramatically transformed the conclusions. Table 6 summarizes the results of trivariate causality tests amongst sterling $M 3$, the price level and the foreign price level. Evidently, when foreign prices are controlled for, it is not possible to reject the hypothesis that sterling M3 causes the domestic price level. This first difference result agrees with the result obtained in the levels and reported in Table 2. There are no other causal relations although the hypothesis that the foreign price level causes the domestic price level for a given value of sterling M3 is close 
Table 5

Is $2 M 3$ Exogenous Under Flexible Rates?

\begin{tabular}{|c|c|c|}
\hline Hypothes is & $\frac{\text { Difference }}{(4,21 \text { d. of f. })}$ & $\begin{array}{l}\frac{\text { Leve } 1}{\left(5,19 \mathrm{~d} . \text { of } f_{.}\right)} \\
F\end{array}$ \\
\hline 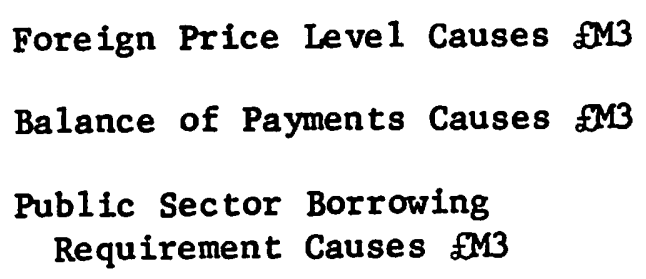 & $\begin{array}{l}0.29 \\
1.57 \\
0.96\end{array}$ & $\begin{array}{l}0.22 \\
0.87 \\
0.27\end{array}$ \\
\hline$F_{0.05}$ & 2.84 & 2.74 \\
\hline
\end{tabular}


Table 6

EM3, Prices and Foreign Prices Under Flexible

Exchange Rates

(First Differences)

\begin{tabular}{|c|c|}
\hline Hypothesis & F \\
\hline$f M 3$ causes price leve1 given foreign price level & $(4,17 \mathrm{~d}$. of f. $)$ \\
fM3 causes foreign price leve1 given price level & $3.34^{\mathrm{c}}$ \\
Foreign price leve1 causes price leve1 given \&M3 & 2.18 \\
Foreign price leve1 causes fM3 given price leve1 & 2.41 \\
Price leve1 causes fM3 given foreign price leve1 & 0.14 \\
Price leve1 causes foreign price level given fM3 & 0.44 \\
\hline Fo.05 (4, 17) & 0.87 \\
\hline
\end{tabular}

Note:

(c) Indicates rejection of the null hypothesis. 
to significance.

Before turning to an attempt at interpretation of these findings, let us summarize them. First, under fixed exchange rates there are no causal links running from money to prices or real activity. Foreign prices cause the monetary base and possibly the domestic price level and real GDP cause sterling $M 3$. Under flexible exchange rates sterling $M 3$ causes the domestic price level but not domestic real GDP. There are no monetary effects on domestic real GDP. Under this exchange rate regime, sterling $\mathrm{M} 3$ is exogenous with respect to the price level, output, the public sector borrowing requirement, foreign prices and the balance of payments.

Let us now turn to the task of attempting to interpret these findings.

VI. TNTERPRETING THE EVIDENCE

The central empirical finding reported above is that $\triangle M B$ causes inflation and does not cause real output flucuations but that this pattern of causal relationships is only observed when the exchange rate is flexible. When the exchange rate is fixed, causation runs from foreign prices to domestic money and from domestic prices and income to money. With which, if any, of the currently available macroeconomic theories are these empirical findings consistent? This question will be addressed in this section. First, the mainstream neoclassical synthesis view in all its many variants and second the rational expectations equilibrium interpretation will be examined.

\section{The Mainstream View}

Most of the major macroeconometric models of the United Kingdom (for example those of the National Institute, the Bank of England, the Treasury, and the London Business School) ${ }^{14}$ have an aggregate demand sector which may be 
summarized as an IS-LM equilibrium of the form

$$
y_{t}=a(L) x_{t}+b(L)\left(m_{t}-p_{t}\right)
$$

where $y=$ real income, $m=\log$ of nominal money, $p$ is the $\log$ of the price level and $x$ is a vector of other variables treated as exogenous. They would include foreign demand, government purchases of goods and services and perhaps even "animal spirits". $a(L)$ and $b(L)$ are polynomials in the lag operator. Most of the existing views of what determines aggregate demand can be represented with equation (7). Even the extreme Cambridge Economic Policy group (see Cripps and Godley (1976)) can be represented by assuming that the lag polynomial $b(L)$ is equal to zero. The "money only matters" view would be represented by setting a(L) equal to zero. The mainstream view concerning the aggregate supply side of the economy may be summarized in an eclectic version of an expectations augmented Phillips curve supplemented with other variables and combined with inertia in the adjustment of inflation expectations. A general enough proposition to encompass all views would be

$$
p_{t}=c(L) x_{t}+d(L) p_{t-1}+e(L) y_{t}
$$

where $c(L), d(L)$ and $e(I)$ again are polynomials in the lag operator $L$. Those at the "monetarist" end of the spectrum would have $c(\mathrm{~L})$ equal to zero, the weights in $d(L)$ summing to unity with $e(L)$ positive. The extremists at the other end of the spectrum would have $e(L)$ equal to zero so that, in effect, prices are exogenous with respect to real income. (See, for example, Henry, Sawyer and Smith (1977) as well as Cripps and Godley (1976).) The eclectic intermediate position would be captured by allowing each of the three polynomials in equation ( 8 ) to be non-zero. This seems to be the view incorporated in the Treasury, London Business School and National Institute 
models (see Laury, Lewis and Ormerod (1978)). Equation (7) (the reduced form aggregate demand function) and equation (8) (the price adjustment or reduced form aggregate supply equation) may be solved for output and prices as functions of the exogenous variables $x$, lagged income and prices and current and lagged values of the money supply. That solution is

$$
\begin{aligned}
& y_{t}=A(L) x_{t}+B(L) m_{t}+G(L) y_{t-1} \\
& P_{t}=C(L) x_{t}+D(L) m_{t}+G(L) p_{t-1}
\end{aligned}
$$

where

$$
\begin{aligned}
& G(L)=(d(L) L-b(L) e(L)) / L \\
& A(L)=[1-d(L) L] a(L)-b(L) c(L) \\
& B(L)=[1-d(L) L] b(L) \\
& C(L)=[a(L) e(L)+c(L)] \\
& D(L)=b(L) e(L)
\end{aligned}
$$

The implications of the various extreme views may now be examined. The "horizontal Phillips curve" view--e(L) $=0$--implies that $D(L)=0$ but $B(L) \neq 0$. This in turn clearly implies that money causes income but money does not cause prices. This is exactly the contrary of the finding reported in the previous section and, therefore, the horizontal Phillips curve assumption is inconsistent with the facts. The vertical Is curve or horizontal IM curve view of the world implies that $b(L)=0$. This in turn would imply that $B(L)=D(L)$ $=0$ so that money causes neither real income nor prices. This again is contrary to the findings reported in the previous section and therefore is an assumption that is not consistent with the facts. The intermediate eclectic position that allows money to have an effect upon aggregate demand and allows some slope to the Phillips curve implies that money causes both income and prices. This too is inconsistent with the findings reported in the previous section. Thus, the mainstream macroeconomic model whether cast in its 
eclectic intermediate mold or in one of its two extreme variations is not consistent with the facts presented in the previous section of this paper. 15 The representation of the mainstream view of macroeconomics in equations (7) and (8) above swept considerations of the open economy into the "other exogenous variable" set, $x$. This is entirely appropriate for the Cambridge Economic Policy group approach which treats the exchange rate as an exogenous instrument of policy and does not seem to do too much violence to the treatment of the exchange rate in the eclectic macroeconometric models. Certainly there is no clear and consistent view as to how the exchange rate, money, prices and income interact in a simultaneous system. That is being lost by the treatment given here.

If the mainstream model is incapable of accounting for the facts, is the rational expectations equilibrium approach able to do any better? It is to that question that attention is now turned.

\section{The Rational Expectations Equilibrium Approach ${ }^{16}$}

A full-scale model of the U.K. economy imposing rationality assumptions in a rigorous way has been developed by Patrick Minford (1980). Other Barro style (see Barro $(1977,1978$ ) and Barro and Rush (1980)) have been conducted by Clifford Attfield, David Demery and Nigel Duck (1981) with some success. The rational expectations approach to macroeconomic model building, like the conventional approach, comes in a variety of forms. In its "sticky wage" form however it is barely distinguishable, at the level of generality being employed here, from the mainstream view summarized above. ${ }^{17}$ It is the equilibrium variant of the rational expectations approach to macroeconomic model building which provides a neat and strong contrast to the mainstream view. Even within the equilibrium approach there are of course a variety of alternative specific models and that employed here is merely illustrative. Employing the 
rational expectations hypothesis and the rationality postulate in general does however impose some discipline on the model building activity not present in the case of the more eclectic neoclassical approach. In particular it is necessary to take a view about how the exchange rate and international aspects of the economy behave as well as domestic aggregate supply and demand.

The simplest framework is one which employs a perfect capital mobility assumption. In that case, portfolio balance together with perfect capital mobility and asset arbitrage determine aggregate demand from the equation

$$
m_{t}-p_{t}=x y_{t}-\eta\left[\left(r_{t}^{*}+E\left(\epsilon_{t+1} \mid I_{t}\right)-\varepsilon_{t}\right]\right.
$$

where $r^{*}$ is the foreign nominal rate of interest, $\varepsilon$ is the log of the foreign exchange rate and $E\left(\mid I_{t}\right)$ is the expectation of a variable conditional on information available at time $t$. This equation is simply the portfolio balance or LM equation with the nominal interest rate replaced by the foreign rate of interest plus the expected rate of depreciation of the currency as determined by asset arbitrage. Assume that aggregate supply is determined by a Lucas style aggregate supply function, that is

$$
y_{t}=\bar{y}+\gamma\left(p_{t}-E\left(\dot{p}_{t} \mid I_{t}\right)\right)+\lambda y_{t-1}
$$

where $\bar{y}$ is trend output. To keep matters simple, assume that the $\log$ of the domestic price level deviates from the $\log$ of the world price level $\left(p_{t}^{*}\right)$ by a random amount $\theta_{t}$. That is,

$$
p_{t}=p_{t}^{*}+c_{t}+\theta_{t}
$$

The solution to this model for the price level and output depends on the exchange rate regime in operation. 


\section{(1) Fixed Exchange Rate}

If the exchange rate is pegged deterministically then equations (11), (12) and (13) determine the price level, real income and the money stock given the exchange rate. If the exchange rate is flexible or 'fixed' but allowed to fluctuate in such a way that its par value might be changed in the future, the equations determine the price level, output and the exchange rate given the money stock. First consider the deterministic exchange rate case. Solving the above model for the three endogenous variables: price, output and the money stock, yields

$$
\begin{aligned}
& p_{t}=p_{t}^{*}+\epsilon+\theta_{t} \\
& \left.y_{t}=\bar{y}+\lambda_{y^{-1}}+\gamma p_{t}^{*}+u_{\theta_{t}}\right)
\end{aligned}
$$

and

$$
\begin{aligned}
m_{t}=x \bar{y} & +\lambda m_{t-1}+x \gamma\left(u_{p_{t}^{*}}+u_{\theta_{t}}\right) \\
& +\left(p_{t}^{*}+\varepsilon+\theta_{t}\right)-\lambda\left(p_{t-1}^{*}+\varepsilon+\theta_{t-1}\right) \\
& -\eta_{r_{t}^{*}}^{*}+\eta \lambda r_{t-1}^{*}
\end{aligned}
$$

where $u_{p_{t}^{*}}$ is the unanticipated component of the foreign price level and $u_{\theta_{t}}$ is the unanticipated component of $\theta$. These solutions are straightforward and in line with well-known results. First, equation (14) follows immediately from (13) and says that the price level will be determined by world prices and by the random international terms of trade shock variable $\theta$, with the exchange rate constant. Real income will fluctuate around its trend value $\bar{y}$ autoregressively and with noise generated by the unanticipated components of foreign prices and real terms of trade shocks. This is directly 
analogous to the closed economy (and flexible exchange rate) result that predicts output fluctuations are associated with unanticipated money. The money stock will be entirely demand determined and will therefore respond to the price level and real income. It is of some interest to note that equation (16) may be rearranged in the following way. First, substitute the domestic price level for the term on the right-hand side of equation (14) that appears in its current and lagged form in equation (16) and second, substitute the domestic rate of interest for the world rate of interest (with perfect capital mobility and fixed exchange rates these are the same). Then rearrange the terms so as to give

$$
\begin{aligned}
m_{t}-p_{t}=x[\bar{y} & \left.+\gamma\left(u_{p_{t}^{*}}+u_{\theta}\right)\right]+\lambda\left(m_{t-1}-p_{t-1}\right) \\
& -\eta r_{t}+\eta \lambda r_{t-1}
\end{aligned}
$$

Equation (17) looks remarkably like (but is not quite identical to) the "demand for money function" formulations used in the empirical studies reviewed in part III above. Real balances depend upon lagged real balances, the current and lagged rate of interest, and a real income variable. The particular real income variable is not current income but trend income plus the noise generated by unanticipated foreign prices and real terms of trade shocks. Assuming that to be pure noise, that would be added to equation (17) as an error term and $\bar{y}$ interpreted as "permanent income". Equation (17) then becomes the "demand for money function" as estimated in many of the studies reported above. It is evident that (17) is in no way a demand for money function. It is a reduced form determining real balances under fixed exchange rates with perfect capital mobility, asset arbitrage and rational expectations. It is of some interest to note that it is that equation which "broke down" as the fixed exchange rate system collapsed and flexible exchange rates ensued. 
On the hypothesis maintained above in equations (11) through (13) that equation would be predicted to break down when the exchange rate regime changed. It is fucther of some interest to note that those attempts to interpret the demand for money as a partial adjustment process are entirely misplaced. Furthermore, equation (17) does not imply any overshooting in the adjustment of income or prices to a change in the money stock. Rather it is the money stock itself which partially adjusts and responds to a change in prices generated by events outside the economy.

What do the reduced forms (14), (15) and (16.) imply about causality? Clearly they imply that money does not cause prices nor does it cause income. Prices are caused by foreign prices and by real terms of trade movements. Presumably foreign prices together with domestic prices are in fact determined simultaneously and caused by world aggregate money. What would be revealed by a causality test which searched for the causal influence of domestic money on income and prices if equations (14)-(17) were true? From equation (15) it is clear that the Granger test of the causal effects of money on income would show no causal relation. This is in agreement with the data. The relation between money and prices can be explored conveniently by writing equations (14) and (16) above in a more compact form. With obvious notational adjustments, write equations (14) and (16) as

$$
\begin{aligned}
& p_{t}=p_{t}^{*}+u_{t} \\
& m_{t}=p_{t}^{*}+\lambda p_{t-1}^{*}+\lambda_{m_{t-1}}+v_{t}
\end{aligned}
$$

The maintained hypothesis embodied in (18) and (19) is that foreign prices cause both domestic prices and domestic money. To see what would happen 
if a causality test of the Granger type was employed which ignored foreign prices and simply looked at causality relations amongst domestic prices and money, eliminate $p *$ between these two equations to give:

$$
m_{t}=p_{t}+\lambda p_{t-1}+\lambda m_{t-1}+v_{t}-u_{t}-\lambda u_{t-1}
$$

or, equivalently,

$$
p_{t}=m_{t}-\lambda p_{t-1}-\lambda m_{t-1}+u_{t}+\lambda u_{t-1}-v_{t}
$$

Clearly if a Granger causality test was performed on fixed exchange rate data it would reveal a symmetrical feedback relation amongst prices and money. This is exactly what we found for the monetary base though we only found causation running from prices (and income) to money in the case of $\mathbb{L M}_{3}$.

\section{(ii) Flexible Exchange Rate}

Under flexible exchange rates the model determines the price level, exchange rate and real income as:

$$
\begin{aligned}
& p_{t}=p_{t}^{*}+\theta_{t}+\frac{1}{1+\eta} \sum_{i=0}^{\infty}\left(\frac{\eta}{1+\eta}\right)^{i} E\left(q_{t+i} \mid I_{t}\right) \\
& c_{t}=\frac{1}{1+\eta} \sum_{i=0}^{\infty}\left(\frac{\eta}{1+\eta}\right)^{i} E\left(q_{t+i} \mid I_{t}\right) \\
& y_{t}=\bar{y}+\lambda y_{t-1}+\frac{\gamma}{1+\gamma \mu}\left(m_{t}-E\left(m_{t} \mid I_{t}\right)\right)
\end{aligned}
$$

where

$$
q_{t+i}=m_{t+i}-p_{t+i}^{*}-\theta_{t+i}-x \bar{y}-x \lambda^{i+1} y_{t-1}+\eta_{r_{t+i}}^{*}
$$

The solution set out above is obtained by calculating the rational expectation of the exchange rate and the price level for future periods and using the forward solution method (see Blanchard (1979)) with terminal stability imposed. As written, the solution to the model is not the final form since the processes generating the exogenous variables have not been specified and used in the 
solution. The form of the rational expectations equilibrium solution for the price level, the exchange rate and real income is entirely standard and in line with the solutions obtained in earlier papers by Lucas (1973) and Barro (1976). It says that the price level and the exchange rate will both be determined by expected future values of exogenous variables (running all the way to the infinite future) those exogenous variables in this case being the money stock, the foreign price level, the foreign rate of interest and the real terms of trade. Real output will fluctuate around its trend autoregressively and disturbed by the contemporaneous innovation in the money supply.

If the world was actually described by the equations set out in (22)-(25) above, what would be found from causality studies of the type conducted and reported in the preceding section? First it is evident that money would not cause income (see equation (24)). Income is predicted to follow an autoregressive path disturbed by white noise $\left(m_{t}-E\left(m_{t} \mid I_{t}\right)\right)$. This is entirely in line with the empirical findings reported. As written, the solution equations for the price level and the exchange rate do not enable strong statements to be made concerning the implications of this model for empirical causality relations. It is necessary to say more about the processes generating the exogenous variables that influence the composite variable, $q$. Let us redefine $q$ as

$$
q_{t}=m_{t}-x_{t}
$$

where $x_{t}$ is the sum of the terms in equation (25) other than the money stock. Notice that all those terms, with the exception of lagged real output, are nominal variables determined in the rest of the world. Thus, as a reasonable simplification, $q_{t}$ may be thought of as being determined by two things, domestic 
monetary policy and world average monetary policy. Under cleanly floating exchange rates there is no necessary connection between in and $x$. However there is also no reason why domestic monetary policy should not in part be responsive to monetary developments in the rest of the world. There is, therefore, no reason why $m$ and $x$ should be independent of each other. There seem to be no strong statements therefore that can be made concerning causality under flexible exchange rates in this rational model. One possibility is that domestic money will cause domestic prices and that domestic prices will be independent of foreign nominal magnitudes. It is equally possible however that monetary policy may itself either react to or be (simultaneously) responsive to foreign nominal shocks in which case both domestic money and foreign prices could appear to have causal influences upon domestic prices. Thus, under flexible exchange rates, causality tests would show that money would have no effect on real activity and would affect prices. It is possible, though not inevitable, that domestic money only would affect prices (with no effects coming from foreign prices). These patterns are, of course, exactly what we observe in the data and report in the previous section.

Thus, in contrast to the mainstream models of macroeconomics, this rational expectations model is not inconsistent with the facts about the causality relations between money and prices. This is not to say, of course, that the particular example of a rational expectations equilibrium model set out above cannot be shown to be inconsistent with some other facts. It does however seem to provide a powerful way of organizing our thinking about how the economy works and is one which at least passes a set of low level tests that are failed by all the other models that have been suggested and that may be found in the literature. 
The conclusions reached here are, of course, strongly at odds with almost all the conclusions reached by others who have studied these phenomena. They are not however entirely inconsistent with some of the empirical findings on demand for money functions and money-income "reduced forms" and causality studies surveyed in sections III and IV of this paper. As was noted there, in the Bank of England (1970) study of the relation between money and income, although not conducting a formal Granger test, Goodhart and Crockett did report that when lagged values of income were included in an income regression on money, no role could be found for money. That is entirely in line with our finding here. Also, the Williams, Goodhart and Gowland and Cuddington findings are in line with our own. Further, the "break down" in demand for money functions following the movement to floating exchange rates in the early 1970 's regarded as an anomaly in need of resolution by a more complex specification of the demand function, is, on the interpretation presented here, not a break down of the demand for money function at all but an implication of the changed external environment.

Although our findings are not out of line with some of the previous empirical results, they are certainly at odds with others (noted extensively above) and with the views expressed by many of those who have studied the role of money in the British economy. The lack of any causal relation between $A M B$ or $M T$ and prices and income and the presence of unidirectional causality between $A M B$ and inflation but no causality between the base and real income seems to deny all the conclusions espoused by those who wrote in the American Economic Review Symposium on Britain (see Ball and Burns (1976), Laidler (1976), Miller (1976) and Williamson and Wood (1976)) as well as the Royal Economic Society's Symposium (see Laidler (1981) and Tobin (1981)). These findings are also inconsistent 
with some of the conclusions (though by no means ali) of the work which came from or was an outgrowth of, the Manchester inflation workshop (see in particular, Parkin $(1974,1975)$ and Laidler and O'Shea (1980)). It may, of course, be possible to "rescue" these mainstream interpretations by controlling for the effects of some "third" variable. We have, however, tried what seem to be the obvious ones in an attempt to 'shake' the results reported in Tables 2-6 and have found those results to be robust.

Interpreting the causality results as rejecting the mainstream models of macroeconomics but as being consistent with the rational expectations equilibrium model appears to get around Sargent's "observational equivalence" conundrum. Actually, in the situation assumed by the rational expectations equilibrium model, a key assumption (assumption (1), p. 632) made by Sargent, is denied for the relation between money and real income. What Sargent does is to assume Granger causality and then show observational equivalence. Since Granger causality is absent, Sargent's theorem does not apply. (See Sargent (1976) and Parkin (1981).)

\section{CONCLUSIONS}

This paper has reviewed the existing empirical literature on demand for money functions, reduced forms between monetary aggregates and output and prices and causality studies and has concluded that on the basis of existing knowledge there is considerable confusion as to whether $A M 3, M$ or any other aggregate is the appropriate intermediate target for monetary policy purposes. It has reported the results of some new causality tests which suggest that $\& \mathbb{B}$ causes inflation under flexible exchange rates but that no monetary aggregate causes real output fluctuations. Under fixed exchange rates 
domestic monetary aggregates cause neither inflation nor output fluctuations. The ability of alternative theories to account for the se facts was reviewed and it was discovered that none of the mainstream macroeconomic models is consistent with the facts. In contrast, the rational expectations equilibrium model is consistent with the facts.

The empirical findings are of course tentative. They certainly are not regarded by us as an unshakable body of dogma. They do however, point in the direction of some additional research that might be fruitful and they also yield tentative policy conclusions.

The research agenda suggested by the results reported here would give a high place to investigating more thoroughly the effects of exogenous foreign variables on domestic prices and income. A search for the "ultimate" exogenous variables, whilst clearly desirable, may not be as promising as beginning by treating foreign prices and interest rates as exogenous to the relatively open United Kingdom economy. Additionally, the role of the exchange rate and interest rates as well as prices and output would help to check out some of the interpretations given in the previous section. Whilst extending the causality testing from a bivariate to a multivariate setting is trivial in principle, it becomes costly in practice in terms of degrees of freedom.

The policy implications of the results and analysis presented here are necessarily tentative. The key conclusion is that the pursuit of a steadier and smoother growth of $2 M 3$ might yield some dividends in terms of inflation and should help considerably to bring real output back to its "natural" level. To address directly the question posed in the title of this paper--is $\operatorname{IN}_{3}$ the right aggregate--the answer seems to be a tentative yes. 


\section{Footnotes}

${ }^{1}$ An important official account of the evolution of policy and the emergence of $A M B$ targeting is available in the Governor of the Bank of England's Mais Lecture (1978).

2 David Savage (1980) provides a table of correlations between various aggregates for annual average data between 1964 and 1978, the correlation between M1 growth and \&M3 growth is 0.395 (Table 1, p. 81).

${ }^{3}$ See Bank of England (1973).

${ }^{4}$ See Artis and Lewis (1976), Table 1, P. 152.

${ }^{5}$ In Part VI below, we do, however, offer a third explanation for the instability in the estimated demand for money functions of the early 1970 s.

${ }^{6}$ This interpretation was apparently suggested first by Paul Evans. See the original Stanford University Center for Research in Economic Growth Research Memorandum No. 234(R), November 1980 version of Cuddington (1981), footnote 11.

${ }^{7}$ Hilliard uses the Sims test on daily data for 250 working days from May 1976 to March 1977.

${ }^{8}$ It seems to us that there must be a fairly straightforward connection between Theil's information concept and Granger's causality concept. We are not however, aware of any statistical work that has explored this connection and made clear the relationship between the tests involved in the two areas.

9 Sims's method, of course, was different from that used here. He employed eight lagged and four led values of the variable for whose causal influence he was testing. In the Sims's method, it is the significance of the coefficients on the led values of the other variable that are relevant. Thus 
our decision to use four lags is in line with Sims's decision to use a lead of four periods in his study. Cuddington explicitly experimented with four-quarter and eight-quarter lags and discovered that moving from four to eight made no significant change in the results.

${ }^{10}$ See Cuddingt on $(1981)$, p. 344 , footnote 1 .

${ }^{11}$ See Wren-Lewis (1981), pp. 10-11.

${ }^{12}$ See Holly and Longbottom (1980), pp. 7 and 8

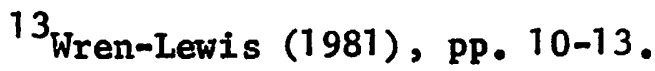

${ }^{14} \mathrm{~A}$ useful brief description and comparison of these models is Laury, Lewis and Ormerod (1978).

${ }^{15}$ An additional fashionable view is that though there is a correlation between money and prices and output, there is a feedback relation amongst the variables. This too is not supported by the facts.

${ }^{16}$ A useful, if slightly hostile, summary of the Rational Expectation literature is Mayes (1981). That article contains a fairly comprehensive bibliography on the subject. Also, a superb analysis of recent economic policy in the U.K. from a rational expectations perspective is provided by Sargent (1981).

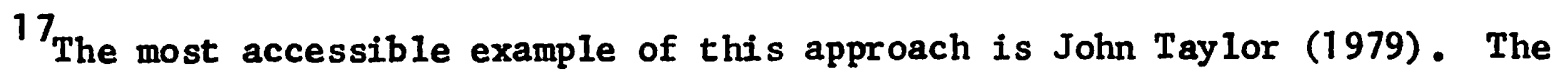
central result of Taylor's model is that output can be influenced by a money stock feedback rule. This is formally equivalent to the proposition that money causes output--a proposition which agrees with the mainstream view but which is not found in the data. 
Akhtar, M. A., and D. S。 Wilford (1979), "The Influence of the United Kingdom's Public Sector Deficit on Its Money Stock, 1973-76," Bulletin of Economic Research, 31, pp. 3-13.

Anderson, L. C., and K. M. Carlson (1970), "A Monetarist Model for Economic Stabilization," Federal Reserve Bank of St. Louis Review (Apri1), pp. 7-23.

Artis, M. J. and M. K. Lewis (1976), "The Demand for Money in the United Kingdom: 1963-1973," The Manchester School (June), pp. 147-77.

Artis, M. J. and A. R. Nobay (1969), "Two Aspects of the Money Debate," National Institute Economic Review, 49 (August), pp. 33-51.

Attfield, C. L. F., D. Demery and N. W. Duck (1981), "A Quarterly Model of Unanticipated Monetary Growth, Output and the Price Level in the U.K.: 963-978," Journal of Monetary Economics, 8, 3, (November), pp. 331-50.

BaIl, R. J. and Terry Burns (1976), "The Inflationary Mechanism in the U.K. Economy," American Economic Review, 66, 4 (September), pp. 467-84.

Bank of England (1973), "Does the Money Supply Really Matter?", Bank of England Quarterly Bulletin, Vol. 13, No. 2 (June), pp. 193-202.

Bank of England (1978), "Reflections on the Conduct of Monetary Policy," Mais Lecture given by the Governor of the Bank of England at the City University, London, 9 February 1978 in Bank of England Quarter ly Bulletin, Vol. 18, No. 1 (March), pp. 31-37.

Barrett, C. R., and A. A. Walters (1966), "The Stability of Keynesian and Monetary Multipliers in the United Kingdom," Review of Economics and Statistics, VoI. XLVII, No. 4 (November), PP.

Barro, Robert J. (1976), "Rational Expectations and the Role of Monetary Policy," Journal of Monetary Economics, 2, pp. 1-32.

(1977), "Unanticipated Money Growth and Unemployment in the United States," American Economic Review, 67, pp. 101-15.

(1978), "Unanticipated Money, Output and the Price Level in the United States," Journal of Political Economy, 86, pp. 549-80. and Mark Rush (1980), "Unanticipated Money and Economic Activity" in Stanley Fischer (ed.), Rational Expectations and Economic Policy, NBER, University of Chicago Press, pp. 23-72.

Beenstock, Michael and Andrew Longbottom (1980), "Portfolio Balance and Inflation in the United Kingdom, "Economic Forecasting Unit Discussion Paper No. 79 (July) (revised February 1981), London Business School.

Blanchard, Olivier J. (1979), "Backward and Forward Solutions for Economies with Rational Expectations," American Economic Review, 66 (May), pp. 114-18. 
Budd, Alan, Sean Holly, Andrew Longbottom and David Smyth (1981), "Does Monetarism Fit the Facts?" Centre for Economic Forecasting, London Business School (September).

Caines, P. E. and C. W. Chan (1975), "Estimation, Identification and Feedback," in Systems Identification: Advances and Case Studies, E. Lainiotis and R. K. Mehta (eds.).

Cripps, Francis and Wynne Godley (1976), "A Formal Analysis of the Cambridge Economic Policy Group Mode1," Economica, 43 (November), pp. 335-48.

Cuddington, John T. (1981), "Money, Income and Causality in the United Kingdom: An Empirical Re-examination," Journal of Money, Credit and Banking, Vol. XIII, No. 3 (August), pP. 342-51.

Davidson, J. E. H., D. F. Hendry, F. Srba and S. Yeo (1978), "Econometric Modelling of the Aggregate Time Series Relationship Between ConsumersExpenditure and Income in the United Kingdom, "Economic Journal (December), pp. 661-92.

Enoch, C. A. (1979), "The Direction of Causality Between the Exchange Rate, Prices and Money," Discussion Paper No. 7, Bank of England, London.

Fisher, Douglas (1968), "The Demand for Money in Britain: Quarterly Results 1951-67," The Manchester School of Economic and Social Studies (December), Pp. 329-44.

Geweke, John, Richard Meese and Warren Dent (1982), "Comparing Alternative Tests of Causality in Intertemporal Systems: Analytic Results and Experimental Evidence," SSRI Workshop Series 8212, Social Systems Research Institute, University of Wisconsin at Madison (Apri1).

Goodhart, C. A. E. and A. D. Crockett (1970), "The Importance of Money," Bank of England Quarterly Bulletin, Vol. 10, No. 2 (June), pp. 159-98.

Granger, Clive W. (1969), "Investigating Causal Relations by Econometric Models and Cross-Spectral Methods," Econometrica, 37, pp. 424-38.

Grice, Joe and Adam Bennett (1981), "The Demand for $2 M 3$ and Other Aggregates in the United Kingdom," H. M. Treasury, mimeo.

Hacche, Graham (1977), "The Demand for Money in the United Kingdom: Experience Since 1971," Bank of England Quarterly Bulletin, Vol. 14, No. 3 (September), PP. 284-305.

Haugh, L. D. (1976), "Checking the Independence of Two Covariants Stationary Time Series: A Univariate Residual Cross Correlation Approach," Journal of the American Statistical Association, Vol . 71, pp. 378-85.

Hendry, D. F. (1980), 'Predictive Failure and Econometric Modelling in Macroeconomics: The Transactions Demand for Money," in Economic Modelling, P. Ormerod (ed.), London, He inemann Educational Books.

Henry, S. G. B., M. C. Sawyer and P. Smith (1976), "Models of Inflation in the United Kingdom," National Institute Economic Review, No. 77 (August), pp. 60-71.

Hilliard, B. C. (1979), "Exchange Flows and the Gilt-Edged Security Market: A Causality Study," Discussion Paper No. 2, Bank of England, London. 
Holly, Sean and Andrew Longbottom (1980), "The Empirical Relationship Between the Money Stock and the Price Level in the U.K.: A Test of Causality," Economic Forecasting Unit Discussion Paper No. 78, Lond on Business School (July).

Kavanagh, N. J., and A. A. Walters (1966), "Demand for Money in the U.K. 1877-1961; Some Preliminary Findings," Bulletin of the Oxford University Institute of Economics and Statistics (May), pp. 93-116.

Laidler, David (1970), "Inflation in Britain: A Monetarist Perspective," American Economic Review, Vol. 66, No. 4 (September), pp. 485-500.

(1981), "Monetarism: An Interpretation and an Assessment," Economic Journal, 91 (March), pp. 1-28.

Laidler, David and Patrick 0'Shea (1980), "An Empirical Macro-Model of an Open Economy Under Fixed Exchange Rates: The United Kingdom 1954-1970," Economica, 47 (May), pp. 141-58.

Laidler, David and Michael Parkin (1970), "The Demand for Money in the United Kingdom 1956-67: Preliminary Estimates," The Manchester School of Economic and Social Studies, Vol. XXXVIII, No. 3 (September), pp. 187-208.

Laury, J. S. E., G. R. Lewis and P. A. Ormerod (1978), "Properties of Macroeconomic Models of the U.K. Economy: A Comparative Study," National Institute Economic Review, 83 (February), pp. 52-72.

Lucas, Robert E. Jr. (1973), "Some International Evidence on Output-Inflation Tradeoffs," American Economic Review, 63, pp. 326-34.

Matthews, K. G. P., and P. A. Ormerod (1978), "St. Louis Models of the U.K. Economy," National Institute Economic Review, No. 85 (August), pp. 65-69.

Mayes, David G. (1981), "The Controversy Over Rational Expectations," Nationa1 Institute Economic Review, No. 96 (May), pp. 53-61.

Miller, Marcus H. (1976), "Can A Rise in Import Prices be Inflationary and Deflationary? Economists and U.K. Inflation," American Economic Review, Vol. 66, No. 4 (September), pp. 501-19.

Mi11s, Terrance, C. (1981), "The Informational Content of the U.K. Monetary Aggregates, "University of Leeds and Bank of England, mimeo (October).

Minford, Patrick (1980), "A Rational Expectations Model of the United Kingdom Under Fixed and Floating Exchange Rates," Carnegie-Rochester Conference Series on Public Policy, Vol. 12 (Spring), pp. 293-355.

Mixon, J. Wilson Jr., Leila J. Pratt and Myles S. Wallace (1979), "CrossNational Money to Income Causality: U.S. Money to U.K. Income," Journal of Money, Credit and Banking, Vol. XI, No. 4 (November), Pp. 419-26. 
Mizon, G. E. (1977), "Model Selection Procedures," in Studies in Modern Economic Analysis, M. J. Artis and A. R. Nobay (eds.), Basil Blackwe11, Oxford.

Parkin, Michael (1974), "United Kingdom Inflation: The Policy Alternatives," National Westminster Bank Review (May).

(1975), "Where is Britain's Inflation Going," Lloyds Bank Review, No. 117 (July), pp. 1-13。

(1981), "Discriminating Between Natural and Unnatural Rate Theories of Macroeconomics," University of Western Ontario Mimeo 1981 and MacQuarie University Centre for Studies in Money, Banking and Finance Working Paper 8102 (May)。

Pierce, D. A. (1977), "Relationships-And the Lack Thereof--Between Economic Time Series with Special Reference to Money and Interest Rates," Journal of the American Statistical Association, Vol. 72, pp. 11-22.

Price, L. L. D. (1972), "The Demand for Money in the United Kingdom: A Further Investigation," Bank of England Quarterly Bulletin, Vol. 12, No. 1 .(March), pp. 43-55.

Putnam, Blueford H. and D. Sykes Wilford (1978), "Money, Income and Causality in the United States and the United Kingdom: A Theoretical Explanation of Different Findings," American Economic Review, Vol. 68, No. 3 (June), PP. 423-27.

Sargent, Thomas J. (1976), "The Observational Equivalence of Natural and Unnatural Rate Theories of Macroeconomics," Journal of Political Economy, 84 (June), pp. 631-40.

(1981), "Stopping Moderate Inflations: The Methods of Poincaré and Thatcher," Economic Policy in the United Kingdom, Proceedings of a Conference, University of Minnesota.

Savage, David (1980), "Some Issues of Monetary Policy," National Institute Economic Review, No. 91 (February), pp. 78-85.

Sims, C. A. (1972), "Money, Income and Causality," American Economic Review, 62 (September), pp. 540-52.

Taylor, John B。(1979), "Staggered Wage Setting in a Macro Mode1," American Economic Review, Vo1。69, No. 2 (May), pp. 108-113.

Tobin, James (1981), "The Monetarist Counter-Revolution Today--An Appraisal," Economic Journal, 91 (March), pp. 29-42.

Wa11, K. D. (1974), "An Application of Simultaneous Estimation to the Determination of Causality Between Money and Income," Programme of Research in Econometric Methods, Discussion Paper No. 8 (April). 
Williams, David, C. A. E. Goodhart and D. H. Gowland (1976), "Money, Income, and Causality: The UK Experience," American Economic Review, Vo1. 66, No. 3 (June), pp. 417-23.

Williamson, John and Geoffrey E. Wood (1976), "The British Inflation: Indigenous or Imported?", American Economic Review, Vo1. 66, No. 4 (September), pp. 520-31.

Wren-Lewis, Simon (1981), "The Role of Money in Determining Prices: A Reduced Form Approach," Government Economic Service Working Paper No. 42 (Treasury Working Paper No. 18), H. M. Treasury, London (March). 
Data Used in Causality Tests

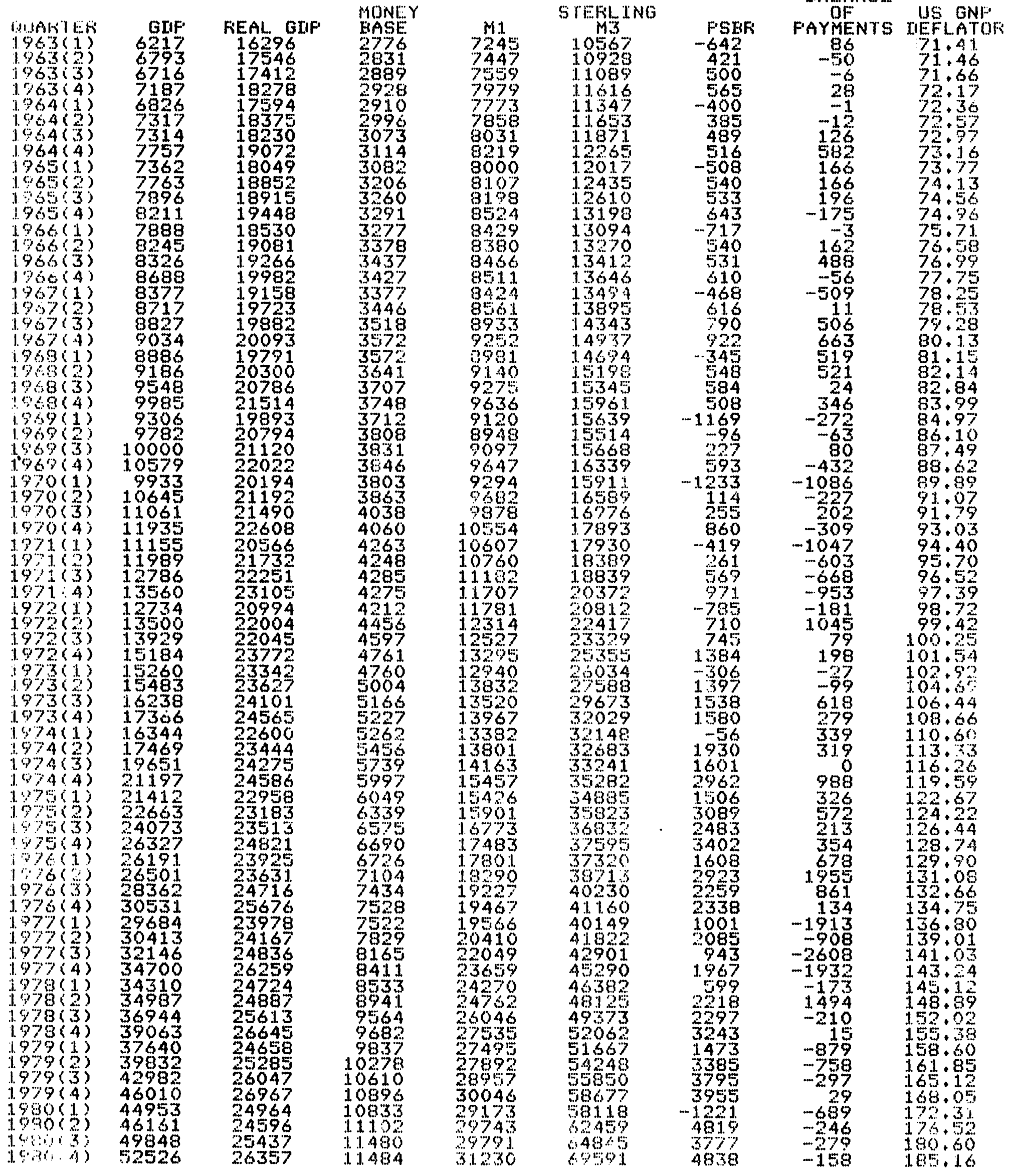


Source: Gross Domestic Product at Factor Cost, Quarterly Series, unadjusted; 1963(1) -1980(4) Economic Trends Annual Supplement, 1982 edition, pp. 10-11.

Gross Domestic Product at Factor Cost, 1975 Prices, Quarterly Series, unad justed;

1963(1)-1980(4) Economic Trends Annual Supplement, 1982 edition, pp. 15-16.

Money Base, average of monthly series, unadjusted;

1963(1) -1980(4) Bank of England Quarterly Bulletin, Vol. 21, No. 1 , March 1981 , pp. 63-64.

M1, Official Series adjusted for breaks, Quarterly Series, unadjusted; 1963 (1) -1979(3) Quarterly Money Stock Series 1963I - 1979III, Bank of England, December 1979 . $1979(4)-1980$ (4) Bank of England Quarterly Bulletin, Vol. 21 , No. 2, June 1982, Table 11.1.

Sterling M3, Official Series adjusted for breaks, Quarterly Series, unad justed;

1963(1)-1979(3) Quarter Iy Money Stock Series 1963I - 1979III, Bank of England, December 1979 . $1979(4)-1980$ (4) Bank of England Quarterly Bulletin, Vol. 21, No. 2, June 1982, Table 11.1.

Public Sector Borrowing Requirement, Quarterly Series;

1963(1) -1980 (4) Economic Trends Annual Supplement, 1982 edition, pp. 154-155.

Balance of Payments (Total Official Financing), Quarterly Series;

1963(1) -1980(4) Economic Trends Annual Supplement, 1982 edition, pp. 126-127.

US GNP Deflator, Quarterly Series, seasonally adjusted;

1963(1) -1976(4) The National Income and Product Accounts of the United

States, 1929-76 Statistical Tables, U.S. Department of Commerce,

September 1981, Pp. 321-322.

1977(1) -1980(4) Survey of Current Business, Vol. 62, No. 7, July 1982, U.S. Department of Commerce, p. 99. 
Data for Figure I

Money Supply Growth Rates

\begin{tabular}{lrrrr} 
& Base & $\underline{M}$ & $\underline{M 3}$ & \&M* \\
1970 & 3.7 & 7.1 & 6.7 & 7.7 \\
1971 & 8.3 & 12.3 & 11.8 & 13.4 \\
1972 & 5.6 & 12.8 & 22.1 & 22.5 \\
1973 & 11.9 & 8.7 & 25.5 & 23.0 \\
1974 & 11.4 & 4.7 & 15.6 & 15.7 \\
1975 & 14.2 & 15.5 & 8.8 & 8.8 \\
1976 & 12.2 & 14.0 & 8.5 & 8.2 \\
1977 & 10.9 & 14.6 & 8.1 & 9.4 \\
1978 & 15.0 & 19.8 & 15.2 & 15.0 \\
1979 & 13.3 & 11.5 & 12.5 & 14.2 \\
1980 & 7.9 & 4.8 & 15.7 & 19.2 \\
\hline Geometric & 9.7 & 10.4 & 12.6 & 13.3 \\
Mean & & & &
\end{tabular}

\section{Source:}

Money Base, see Data Appendix.

$M 1$ and $\mathfrak{A M} 3$, Official Series adjusted for breaks, average of unadjusted series;

1969-1978, Quarter Iy Money Stock Series 1963I-1979III, Bank of England, December 1979.

1979-1980, Bank of England Quarterly Bulletin, Vo1. 21, No. 2, June 1981, Table 11.1

EMB* is the sum of $A M 3$ and overseas sector sterling deposits with the banking sector, annual average of quarterly series;

1969-1973, Bank of England Statistical Abstract, No. 2, 1975, Table 12/1. 1974-1976, Bank of England Quarterly Bulletin, Vol. 18, No. 4, December 1978, Table 6.1.

1977, Bank of England Quarterly Bulletin, Vo1. 19, No. 4, December 1979, Table 6 .

1978, Bank of England Quarterly Bulletin, Vol. 20, No. 4, December 1980, Table 6. 1979-1980, Bank of England Quarterly Bulletin, Vol. 21, No. 1, March 1981. 


\section{$-3-$}

$\underline{1982}$

8201C Manning, Richard and James R. Markusen: DYNAMIC NON-SUBSTITUTION AND LONG RUN PRODUCTION POSSIBILITIES

8202C Feenstra, Robert and Ken Judd: TARIFFS, TECHNOLOGY TRANSFER, AND WELFARE

8203C Ronald W. Jones and Douglas D. Purvis: INTERNATIONAL DIFFERENCES IN RESPONSE TO COMMON EXTERNAL SHOCKS: THE ROLE OF PURCHASING POWER PARITY

$8204 \mathrm{C}$ James A. Brander and Barbara J. Spencer: INDUSTRIAL STRATEGY WITH COMMITTED FIRMS

8205C Whalley, John: THE NORTH-SOUTH DEBATE AND THE TERMS OF TRADE: AN APPLIED GENERAL EQUILIBRIUM APPROACH

8206C Betancourt, Roger; Christopher Clague and Arvind Panagariya: CAPITAL UTILIZATION IN GENERAL EQUILIBRIUM

8207C Mansur, Ahsan H.: ON THE ESTIMATION OF IMPORT AND EXPORT DEMAND ELASTICITIES AND EIASTICITY PESSIMISM

8208C Whalley, J. and Randy Higle: PRICE AND QUANTITY RIGIDITIES IN ADJUSTMENT TO TRADE POLICY CHANGES: ALTERNATIVE FORMULATIONS AND INITIAL CALCULATIONS

8209C DSU Jimenez, E.: SQUATTING AND COMMUNITY ORGANIZATION IN DEVELOPING COUNTRIES: A CONCEPTUAL FRAMEWORK

$8210 C$ Grossman, G.M.: INTERNATIONAL COMPETITION AND THE UNIONIZED SECTOR 8211C Laidler, D.: FRIEDMAN AND SCHWARTZ ON MONETARY TRENDS--A REVIEW

8212C Imam, $\mathrm{H}$. and John Whalley: INCIDENCE ANALYSIS OF A SECTOR SPECIFIC MINIMUM WAGE IN A TWO SECTOR HARRIS-TODARO MODEL

$8213 \mathrm{C}$ Markusen, James R. and James R. Melvin: THE GAINS FROM TRADE THEOREM WITH INCREASING RETURNS TO SCALE

8214C Harris, Richard: INDUSTRIAL ORGANIZATION AND THE GENERAL EQUILIBRIUM COSTS OF PROTECTION IN SMALL OPEN ECONOMIES

8215C Laidler, David: DID MACROECONOMICS NEED THE RATIONAL EXPECTATIONS REVOLUTION?

8216C John Whalley and Randall Wigle: ARE DEVELOPED COUNTRY MULTILATERAL TARIFF REDUCTIONS NECESSARILY BENEFICIAL FOR THE U.S.? 